\title{
Eksistensi Surat Perintah Penghentian Penyidikan Dalam Diskursus Kepentingan Korban
}

\author{
Eddy Hariyanto \\ Kaspk.reskukar@gmail.com \\ Kanit Reskrim Polsek Loajanan, Polres Kutai Kartanegara
}

\begin{abstract}
ABSTRAK
Penelitian ini diajukan untuk menjawab tiga hal yaitu apakah surat kesepakatan antara pelaku dan pihak korban dapat menjadi instrumen hukum dalam menilai peristiwa korban jiwa manusia menurut hukum pidana Indonesia, apakah terjadi pergeseran persepsi sosial, korban dan penegak hukum dalam menilai alasan peniadaan pertanggungjawaban hukum pidana atas hilangnya nyawa dengan kualifikasi culva lata (bewuste schuld) dan dolus eventualis dan bagaimanakah pengaturan Surat Perintah Penghentian Penyidikan terhadap kasus korban meninggal dunia pada sasaran penyidikan yang melibatkan korporasi. Pendekatan penelitian yang digunakan adalah social legal research dengan membangun variabel sebagai dasar pengukuran isu hukum yang dibangun. Dalam pendekatan ini, variabel mengenai perdebatan dalam kerangka teori, perdebatan pada tingkat penyidikan terkait penerbitan surat perintah penghentian penyidikan dalam kasus meninggalnya nyawa manusia di lubang tambang dengan norma yang berlaku. Surat kesepakatan yang dibuat oleh pelaku dan pihak korban dalam peristiwa hilangnya jiwa seseorang sejatinya tidak serta merta menghapus pertanggungjawaban pidana terhadap yang melakukannya. Namun tidak bisa dipungkiri dalam hukum pidana Indonesia mengenal penyelesaian sengketa diluar pengadilan yang sering dinamakan mediasi penal yang merupakan tradisi dari hukum adat budaya Indonesia yang memberikan penghargaan terhadap penyelesaian secara musyawarah terhadap pelaku dan korban dalam menyelesaikannya secara bersama-sama sehingga mendapatkan kesepakatan untuk berdamai yang kita kenal dengan sistem restorative justice. Sehingga dari kesepakatan perdamaian yang dibuat itulah dapat menjadi dasar pertimbangan penyidik untuk menerbitkan surat perintah penghentian penyidikan.
\end{abstract}

\section{Kata Kunci: Surat Penghentian Penyidikan, Lubang Tambang, Pertanggungjawaban Pidana}




\begin{abstract}
This research aimed to answer three questions: Can the agreement letter between the offender and the victim become a legal instrument in assessing the victim of human life according to Indonesian criminal law? Is there any change in social perception, both the victims and law enforcers, in assessing the reasons for the discharge of criminal law responsibility for the loss of human life with a qualification of gross negligence or culpa Iata (bewuste schuld) and dolus enentuals? And how was the Warrant for the Termination of Investigation arranged towards the case of victims who passed away related to the target of investigation involving a corporation? This research applied social legal research in which the variables were constructed as a basic for the assessment of constructed legal issues. In this approach, the variables consisted of debates on the theoretical framework and debates at the level of investigation concerning the issuance of the warrant for the termination of investigation in the case of the victim who was killed in the mining tunnel, based on the applicable norms.

Agreement letter which was made by the offender and the victim party concerning the loss of one's life should not automatically discharge the responsibility of the criminal defendant. However, it cannot be denied that Indonesian criminal law makes it possible to resolve a dispute outside the court. This is called a penal mediation which is a part of Indonesian traditional and cultural law which gives an appreciation to the resolution made based on the result of deliberation between the offender and the victim. The dispute in this case was settled together to obtain a peace or restitution agreement, which is usually called restorative justice system. The peace or restitution agreement becomes a basic for investigator's consideration to issue a warrant for the termination of investigation.
\end{abstract}

\title{
Keywords: Termination of Investigation, Mining Tunnel, Criminal Responsibility
}

\section{PENDAHULUAN}

\section{A. Latar Belakang}

Pengakuan dan perlindungan Hak Asasi Manusia merupakan salah satu ciri dari negara hukum. Negara Indonesia merupakan negara yang berlandaskan atas hukum sesuai dengan bunyi Pasal 1 ayat (3) Undang-Undang Dasar Negara Republik Indonesia Tahun 1945 bahwa "Negara Indonesia adalah negara hukum." Hak Asasi manusia adalah hak dasar atau kewarganegaraan yang melekat pada individu sejak ia lahir secara kodrat yang diberikan langsung oleh Tuhan Yang Maha Esa yang tidak dapat dirampas dan dicabut keberadaannya dan wajib dihormati, dijunjung tinggi, dan dilindungi oleh negara, hukum, pemerintah dan setiap orang demi kehormatan dan perlindungan harkat dan martabat manusia. Usaha pertambangan adalah kegiatan dalam rangka pengusahaan mineral atau batubara yang meliputi tahapan kegiatan penyelidikan umum, eksplorasi, studi kelayakan, konstultasi, penambangan, pengolahan dan pemurnian, pengangkutan dan penjualan, serta pascatambang. Undang-Undang Nomor 4 Tahun 2009 tentang Pertambangan Mineral dan Batubara, yang tertuang pada Pasal 1 angka 1 menjelaskan bahwa pertambangan adalah sebagian atau seluruh tahapan kegiatan dalam rangka penelitian, pengelolaan dan pengusahaan mineral atau batubara yang meliputi penyelidikan umum, eksplorasi, 
studi kelayakan, kontruksi, penambangan, pengelolaan dan pemurnian.

Undang-Undang Nomor 4 Tahun 2009 tentang Pertambangan Mineral dan Batubara, yang tertuang pada Pasal 1 angka 1 menjelaskan bahwa "Pertambangan adalah sebagian atau seluruh tahapan kegiatan dalam rangka penelitian, pengelolaan dan pengusahaan mineral atau batubara yang meliputi penyelidikan umum, eksplorasi, studi kelayakan, kontruksi, penambangan, pengelolaan dan pemurnian, pengangkutan dan penjualan, serta kegiatan pascatambang."

Keberadaan perusahaan tambang diindonesia kini banyak dipersoalkan oleh berbagai kalangan. Ini disebabkan keberadaan perusahaan tambang itu telah menimbulkan dampak negatif didalam pengusahaan bahan galian. Dampak negatif dari keberadaan perusahaan tambang,meliputi: Rusaknya hutan yang berada di daerah lingkar tambang; Tercemarnya laut; Terjangkitnya penyakit bagi masyarakat yang bermukim di daerah lingkar tambang; Konflik antar masyarakat lingkar tambang dengan perusahaan. ${ }^{1}$

Di Indonesia, Kalimantan Timur adalah salah satu dari Provinsi utama penghasil batubara, pada masa Orde Baru, sebelum masa otonomi daerah, ijin tambang di Kalimantan Timur meliputi 69 Ijin Kuasa Pertambangan (KP), 9 Ijin Kontrak Karya (KK) dan 40 Ijin Perjanjian Karya pengusahaan Pertambangan Batubara (PKP2B), dengan total ijin adalah 118 buah. Jumlah ijin ini meningkat hampir 13 kali lipat pada masa otonomi daerah menjadi 1.488 Ijin Usaha Pertambangan. ${ }^{2}$

Akibat dari banyaknya izin tambang batubara yang dikeluarkan tersebut

1 Salim HS, 2012. Hukum Pertambangan Indonesia. Rajawali Pers, Jakarta, hal.5

2 Basyir Daud, 2017, Samarinda Menggugat; ketika kegelisahan menjadi kemarahan, Jaringan Advokasi Tambang (JATAM), Jakarta, hal.3 menimbulkan berbagai permasalahan di dalam masyarakat yaitu salah satunya penambangan di kawasan daerah padat pemukiman penduduk yang dimana perusahaan banyak melakukan penambangan dengan sistem terbuka (open pit mine) sehingga menyebabkan banyak korban meninggal di lubang-lubang bekas tambang. Dari hasil pemantauan Komnas Hak Asasi Manusia sejak 2011 ada sebanyak 28 (dua puluh delapan) kasus orang meninggal dunia akibat lubang yang dibiarkan terbuka. ${ }^{3}$ Dimana baru 1 (satu) perkara yang masuk sampai pada tingkatan Pengadilan Negeri dengan hukuman penjara selama 2 (dua) bulan. Untuk menyelesaikan kasus-kasus korban meninggal di lubang bekas tambang oleh pihak kepolisian tentunya banyak menghadapi kendala seperti belum ada bukti yang jelas terhadap korban yang meninggal di lubang bekas tambang, pihak keluarga korban yang tidak mau melakukan otopsi terhadap mayat korban, dan sebagainya. yang tentunya hal tersebut mempersulit kepolisian untuk mengungkat kasus yang sebenarnya. Namun di satu sisi pihak kepolisian sebagai penegak hukum diharapkan dapat menjamin tegaknya hukum dengan menjunjung hak asasi manusia sehingga dapat memberikan kepastian hukum kepada masyarakat khususnya kepada para keluarga korban.

Hukum pidana dengan karakternya yang tegas dan memiliki tingkat presisi dari sisi kepastian hukum mengalami penurunan tingkat daya mengikat (reduksi nilai) bilamana kepentingan pihak korban ikut menjadi pertimbangan dalam proses penegakan hukum. Basis penentuan kesalahan lebih difahami sebagai urusan teknis hukum acara dengan meniadakan aspek-aspek rangkaian peristiwa pidana

3 https://www.jatam.org/2017/07/05/lagilubang-maut-batu-bara-makan-korban/ diakses pada tanggal 30 Juli 2017, Pukul 20.06 Wita 
yang telah menimbulkan akibat hukum. Penilaian aspek memulihkan keadilan sosial (social justice) terkoreksi persepsi penilaian dan ukuran lembaga penyidikan dan ketidakmampuan korban mengartikulasikan prinsip perlindungan umum dan pribadi yang diusung oleh hukum pidana (substantive law) direduksi karena pilihan normatif-argumentatif pada konstruksi hukum berupa penghentian penyidikan.

\section{B. Rumusan Masalah}

Berdasarkan uraian latar belakang rumusan masalah sebagai berikut :

1. Apakah surat kesepakatan antara pelaku dan pihak korban dapat menjadi instrumen hukum dalam menilai peristiwa korban jiwa manusia menurut hukum pidana Indonesia?

2. Apakah terjadi pergeseran persepsi sosial, korban dan penegak hukum dalam menilai alasan peniadaan pertanggungjawaban hukum pidana atas hilangnya nyawa dengan kualifikasi culva lata (bewuste schuld) dan dolus eventualis?

3. Bagaimanakah pengaturan Surat Perintah Penghentian Penyidikan terhadap kasus korban meninggal dunia pada sasaran penyidikan yang melibatkan korporasi ?

\section{Tujuan Penelitian}

Berdasarkan latar belakang dan rumusan masalah sebagaimana diuraikan diatas, tujuan penelitian ini diarahkan untuk menjawab 3 (tiga) hal yaitu :

Pertama, Penulis ada melihat kejelasan terkait apakah. surat kesepakatan antara pelaku dan pihak korban dapat menjadi instrumen hukum dalam menilai peristiwa korban jiwa manusia menurut hukum pidana Indonesia. Pada bagian ini, penelitian ingin mengidentifikasi terkait keabsahan surat kesepakatan sebagai suatu instrumen hukum sehingga dapat menjadi acuan diterbitkannya surat perintah penghentian penyidikan;

Kedua, Penulis menganalisis apakah terjadi pergeseran persepsi sosial, korban dan penegak hukum dalam menilai alasan peniadaan pertanggungjawaban hukum pidana atas hilangnya nyawa dengan kualifikasi culva lata (bewuste schuld) dan dolus eventualis. Pada bagian ini, penelitian mencoba menelusuri permasalahan yang ada dengan teori-teori hukum untuk menemukan jawaban dari sisi hukum;

Ketiga, Ingin mengetahui kejelasan pengaturan surat perintah penghentian penyidikan terhadap kasus korban meninggal dunia pada sasaran penyidikan yang melibatkan korporasi. Pada bagian ini, penelitian diarahkan untuk mengidentifikasi kesesuaian antara peraturan dengan pelaksanaan termasuk mengidentifikasi faktor-faktor munculnya surat perintah penghentian penyidikan.

\section{Manfaat Penelitian \\ 1. Manfaat Teoritis}

Penelitian ini diharapkan dapat memberikan kontribusi pemikiran dalam pertanggungjawaban pidana khususnya berkaitan dengan eksistensi surat perintah penghentian penyidikan dalam diskursus kepentingan korban dalam hal hilangnya nyawa seseorang di lubang tambang.

\section{Manfaat Praktis}

Penelitian ini diharapkan kelak diharapkan dapat memberikan pengetahuan dalam hal penyelesaian tindak pidana terhadap hilangnya nyawa seseorang di lubang tambang melalui mekanisme di luar sistem hukum pidana.

\section{METODE PENELITIAN}

\section{Pendekatan Penelitian}

Dalam penelitian ini, Pilihan pendekatan pada doctrinal dengan alasan 
salah satu sasaran studi ini melihat seperangkat norma positif dalam kaitannya dengan eksistensi surat perintah penghentian penyidikan dalam diskursus kepentingan korban, termasuk dukungan sisi teori hukum dengan tujuan untuk mendapatkan kejelasan apakah dengan adanya surat kesepakatan yang dibuat oleh pelaku dan pihak korban adalah merupakan pergeseran persepsi sosial sehingga dapat menjadi alasan peniadaan pertanggungjawaban hukum pidana atas hilangnya nyawa seseorang dan penyidik dapat mengeluarkan surat perintah penghentian penyidikan.

\section{Lokasi Penelitian}

Penelitian akan dilakukan dengan melakukan wawancara terhadap keluarga korban di kelurahan Sambutan Samarinda, di lokasi tambang PT.Hymco Coal dan PT.Panca Prima Mining serta mengumpulkan data-data terkait isu hukum yang diambil di Kantor Polresta Kota Samarinda.

\section{Sumber Data}

Penggunaan bahan sekunder berupa bahan kepustakaan dikelompokan sebagai berikut: pertama, bahan hukum yang relevan terkait surat perintah penghentian penyidikan, kedua, oleh karena penelitian ini merupakan penelitian hukum maka membutuhkan dukungan pustaka tentang teori hukum (konsep-konsep hukum seperti pertanggungjawaban pidana, kesalahan, kesengajaan, dan kelalaian). Data empirik diperoleh melalui wawancara dengan keluarga korban yang meninggal di lubang tambang dan wawancara dengan kepolisian kota Samarinda.

\section{Analisis Data}

Data yang diperoleh selama penelitian akan dianalisis secara kualitatif untuk mendeskripsikan jawaban atas pertanyaan penelitian:

\section{Rumusan masalah (R1)}

Data yang diperoleh selama penelitian diarahkan untuk menganalisis surat kesepakatan antara pelaku dengan keluarga korban apakah dapat menjadi instrumen hukum dalam menilai peristiwa korban jiwa manusia menurut hukum pidana di Indonesia. Dalam hal ini membutuhkan pendekatan secara hukum mengenai kesepakatan dalam aspek hukum pidana Indonesia dan konstruksi hukum (argumentasi hukum).

Rumusan masalah ( $R 2)$

Terdapat dua variabel utama dalam bagian hal ini, yaitu Pertama, persepsi sosial, korban dan penegak hukum dalam hal peniadaan pertanggungjawaban pidana. Analisis pada bagian ini melihat dari sisi teori hukum, konsep-konsep hukum yang berhubungan dengan pertanggung jawaban pidana. Yang kemudian dihubungkan dengan hasil wawancara dengan keluarga korban dan pihak kepolisian sehingga dapat menjadi suatu konstruksi hukum terkait apakah terjadi pergeseran persepsi sosial, keluarga korban dan penegak hukum. Kedua, dengan hilangnya nyawa seseorang dikaitkan dengan kualifikasi culva lata (kelalaian berat) dan dolus eventualis (kesengajaan) dapat menjadi alasan peniadaan pertanggungjawaban hukum pidana. Pada bagian ini, penilaian terhadap prinsip-prinsip kesalahan yaitu kelalaian dan kesengajaan.

Rumusan masalah (R3)

Data yang diperoleh dari kepolisian kota Samarinda untuk mendapatkan kejelasan pengaturan surat perintah penghentian penyidikan terhadap kasus korban meninggal dunia sehingga 
dengan adanya surat kesepakatan antara pelaku (pihak korporasi) dan keluarga korban dapat menjadi alasan peniadaan pertanggungjawaban hukum pidana.

\section{HASIL DAN PEMBAHASAN}

\begin{tabular}{lrrr} 
SURAT & \multicolumn{2}{c}{ KESEPAKATAN } & ANTARA \\
PELAKU & DAN & PIHAK & KORBAN \\
SEBAGAI & INSTRUMEN & HUKUM \\
DALAM & MENILAI & PERISTIWA \\
HILANGNYA & JIWA & MANUSIA \\
MENURUT & HUKUM & PIDANA \\
INDONESIA & &
\end{tabular}

\section{A. Kesepakatan Penyelesaian Tindak Pidana Dalam Perspektif Ilmu Hukum Pidana}

Kesepakatan dalam hukum dibuat agar terciptanya perdamaian antara kedua belah pihak yang bersengketa, yang mana rasio dari perdamaian tersebut adalah secara preventif untuk mencegah kemungkinan timbulnya suasana permusuhan yang berkelanjutan di kemudian hari antara pihak-pihak yang berperkara. Selain itu juga dengan adanya perdamaian yang dicantumkan dalam surat kesepakatan bersama tersebut maka menghindari penyelesaian secara hukum melalui pengadilan yang mana menghindari biayabiaya yang timbul selama proses berpekara di pengadilan dan menghindari waktu yang lama dalam menyelesaikan permasalahan yang ada. Mengingat pula bahwa keputusan hakim akan memberikan putusan yang kalah dan yang menang sehingga akan merugikan salah satu pihak apalagi masih adanya hubungan dalam keluarga. Dasar yang menjadi alasan perdamaian dalam suatu tindak pidana adalah karena tujuan pemidanaan itu bukan serta merta untuk memberikan hukuman seberat-beratnya kepada seseorang ke dalam penjara. Sehingga penyelesaian perkara di luar pengadilan seringkali dipergunakan untuk menyelesaikan permasalahan yang ada melalui suatu mediasi yang bertujuan menghasilkan kesepakatan untuk suatu perdamaian, yang dalam hukum pidana dikenal dengan mediasi penal merupakan perkembangan baru dalam ranah hukum pidana yang membawa implikasi mulai diterapkannya dimensi bersifat privat ke dalam ranah hukum publik. Mediasi penal tidak diatur dalam undang-undang melainkan hanya diatur secara parsial dan terbatas berupa Surat KAPOLRI Nomor Pol:B/3022/XII/2009/ SDEOPS tanggal 14 Desember 2009 tentang Penanganan Kasus Melalui Alternative Dispute Resolution (ADR) serta Peraturan Kepala Kepolisian Negara Republik Indonesia Nomor 7 Tahun 2008 tentang Pedoman Dasar Strategi dan Implementasi Pemolisian Masyarakat Dalam Penyelenggaraan Tugas Polri. Pada dasarnya, peraturan tersebut mengatur tentang penanganan kasus pidana melalui Alternative Dispute Resolution (ADR) dengan sifat kerugian materi kecil, disepakati para pihak, dilakukan melalui prinsip musyawarah mufakat, harus menghormati norma sosial/adat serta memenuhi asas keadilan dan apabila dicapai melalui Alternative Dispute Resolution (ADR) pelakunya tidak lagi disentuh oleh tindakan hukum lainnya. ${ }^{4}$

Praktik peradilan pidana umumnya menjadikan perdamaian yang dilakukan antara korban dengan pelaku tindak pidana menjadi bahan pertimbangan meringankan yang digunakan oleh sebagian besar hakim dalam menjatuhkan putusannya. Perdamaian yang dilakukan antara korban dengan pelaku tindak pidana tidak dapat menghapuskan pertanggungjawaban atau perbuatan yang telah dilakukan oleh

${ }^{4}$ Lilik Mulyadi, 2016, Implementasi Mediasi Penal Sebagai Perwujudan Nilai-Nilai Pancasila GunaMendukung SupremasiHukum Dalam Rangka Pembangunan Hukum Nasional, Genta Publishing, Yogyakarta, hal.31 
terdakwa meskipun sudah ada surat pernyataan yang dibuat oleh pelaku dan korban yang pada intinya korban sudah memaafkan terdakwa dan tidak akan menuntut terdakwa atas perbuatannya, bahkan meminta petugas untuk membebaskan terdakwa dari pemidanaan. Alasan dalam praktik pengadilan bahwa perdamaian antara korban dengan pelaku tindak pidana tidak dapat menghapuskan pemidanaan menurut alfe musyahadah antara lain: ${ }^{5}$

a. Perkara yang dilakukan bukan merupakan delik aduan sehingga tetap tidak dapat menghapus pertanggungjawaban pidana;

b. Perdamaian yang dilakukan antara korban dengan pelaku fungsinya sebagai pendekatan humanity dalam menjatuhkan pidana, seperti usia yang muda, wanita hamil, tulang punggung keluarga, dan

c. Dalam perkara pidana, perdamaian masih terbuka pada tingkat penyidikan sedangkan jika perkara sudah sampai ke tingkat pengadilan/mulai diperiksa di persidangan, maka hakim akan memeriksa berdasarkan surat dakwaan yang diajukan oleh jaksa penuntut umum.

Para hakim yang visioner atau berwawasan luas dan jauh ke depan akan selalu mempertimbangkan agar perkara pidana yang sedang diperiksa dan diputuskan dapat memenuhi rasa keadilan baik bagi pelaku tindak pidana maupun bagi pihak korban. Tidak semua hakim yang menangani perkara pidana memiliki kepekaan dalam menangkap tanda-tanda yang menyertai perkara yang ditanganinya sehingga perlu diberikan perhatian ekstra

5 Alef Musyahadah R, 2005, "Kedudukan Perdamaian Antara Korban Dengan Pelaku Tindak Pidana Dalam Sistem Pemidanaan" Tesis, Program Pasca Sarjana Universitas Diponegoro, Semarang, hal.142 kepada kondisi psikis pihak korban dan pelaku tindak pidana. Hanya hakim yang berwawasan progresif dapat melakukan perdamaian antara pelaku tindak pidana dengan korban yang telah disakiti atau dirugikannya, baik dengan sengaja ataupun karena kelalaiannya. Dengan memerintahkan terdakwa untuk meminta maaf kepada korban,dan menyatakan penyesalan atas perbuatan yang telah menyakiti korban, dengan dilakukan secara tulus dan ikhlas akan memberikan pengaruh positif berupa pemulihan trauma psikis yang dialami korban, selain itu juga menjadi insentif bagi pelaku dengan keringanan pemidanaan.

Sistem peradilan pidana dewasa ini masih menganut konsep bahwa perkara pidana adalah merupakan sengketa antara individu dengan masyarakat (publik) dan sengketa itu akan diselesaikan oleh Negara (pemerintah) sebagai wakil dari publik. Sekalipun HIR telah digantikan KUHAP tetapi konsep itu tetap belum berubah. Sengketa itu sendiri adalah berhubungan dengan salah satu atau beberapa substansi daripasal yang sudah diatur dan diancam dengan hukuman dalam hukum pidana materiil yang saat ini ditentukan dalam KUHP dan di luar KUHP. Individu terlibat dalam sengketa itu yakni sebagai subjek hukum disebut tersangka atau terdakwa. Dalam penyelesaian sengketa ini dianut suatu konsep bahwa Negara akan selalu berbuat baik bagi warga negaranya termasuk para pencari keadilan dalam perkara pidana.

Secara asas, permusyawaratan (nilai sila keempat Pancasila) yang digunakan sebagai sarana perdamaian sehingga menghasilkan pemaafan diantara pelaku dan korban maupun keluarga serta masyarakat yang berkepentingan merupakan elemen utama dari pola penyelesaian perkara yang secara historissosiologis telah ada di dalam berbagai 
masyarakat di Indonesia sejak zaman prakolonialisme, kemudian tergerus pada zaman kolonialisme yang menghendaki penerapan positivisme dan kodifikasi hukum yang bersifat individualisme. Maka perlu ada pembaruan hukum pidana nasional yang berorientasi pada upaya dekolonialisasi KUHP peninggalan/warisan kolonial, demokratisasi hukum pidana, konsolidasi hukum pidana, dan adaptasi dan harmonisasi terhadap berbagai perkembangan hukum yang terjadi baik sebagai akibat perkembangan di bidang ilmu pengetahuan hukum pidana maupun perkembangan nilai-nilai, standar-standar serta norma yang hidup dan berkembangan dalam kehidupan masyarakat hukum Indonesia dan dunia internasional, sekaligus sebagai refleksi kedaulatan nasional yang bertanggungjawab.

$\begin{array}{ccr}\text { Nilai } & \text { kerakyatan } & \text { dan } \\ \text { permusyawaratan } & \text { perwakilan } & \text { dalam }\end{array}$

Pancasila harus dimanivestasikan dalam pembentukan norma hukum pidana menggunakan prosedur yang demokratis, terbuka, adil, dan partisipatif. Seperti faham legalitas juga mempertimbangkan nilai-nilai hukum yang hidup di dalam masyarakat. Seperti dalam RUU KUHP Pasal 1 ayat (3) menegaskan keberpihakan pada nilai-nilai hukum yang hidup dalam masyarakat. Ketentuan ini tidak mengurangi berlakunya hukum yang hidup dalam masyarakat yang menentukan bahwa seseorang patut dipidana walaupun perbuatan tersebut tidak diatur dalam peraturan perudang-undangan, sepanjang sesuai dengan nilai-nilai Pancasila dan/atau prinsip-prinsip hukum umum yang diakui oleh masyarakat bangsabangsa. Diberikannya ruang/peluang untuk menyelesaikan lewat mekanisme mediasi dalam perkara pidana (mediasi penal). Perdamaian yang didasari adanya kebutuhan pemaafan perlu dielaborasi dalam proses penanganan perkara pidana, baik sebelum atau di luar pengadilan maupun saat atau dalam proses persidangan di pengadilan. Sebagaimana praktik pemberian diyat dalam hukum Islam yang pada hakikatnya merupakan bentuk perlindungan kepada korban kejahatan di satu pihak, di lain pihak merupakan bentuk pidana pengganti karena dilaksanakannya ajaran pemaafan yang sangat dianjurkan dalam Al Qur'an danSunah Nabi. Pemberian diyat juga melindungi serta meringankan beban tersangka. Selain itu, dengan pemberian diyat mengembangkan prinsip kedamaian hidup antar manusia dan dengan semangat silaturahim dan saling memaafkan terhadap segala kemungkinan kesalahan dalam pergaulan bersama dalam masyarakat.

Penyelesaian perkara yang tidak memenuhi rasa keadilan bagi para korban tindak pidana, telah diakui oleh berbagai pihak dapat mendorong terjadi tindakan balas dendam dari korban dan keluarganya terhadap pelaku tindak pidana dan keluarganya. Sejalan dengan perkembangan hukum pidana modern, perdamaian yang dilakukan antara korban dengan pelaku tindak pidana dengan diikuti ganti rugi atas terjadinya tindak pidana perlu dikembangkan kebijakan pengaturannya dalam pembaruan hukum pidana nasional.

Rancangan undang-undang KUHP (tahun 2015) telah mengakomodasi bahwa pengaruh tindak pidana terhadap korban atau keluarganya dan pemaafan dari korban dan/atau keluarganya menjadi dasar pertimbangan dalam pemidanaan. Pemberian ganti kerugian yang layak atau perbaikan kerusakan secara sukarela sebagai akibat tindak pidana yang dilakukan menjadi faktor peringanan pidana. Bahkan dimungkinkannya hakim memberi maaf/ pengampunan ("rechterlijkpardon") tanpa menjatuhkan pidana/tindakan apapun terhadap terdakwa, sekalipun telah terbukti adanya tindak pidana dan kesalahan. Pada rumusan yang 
ada dalam pembaruan hukum pidana nasional tersebut di atas, hakim diberikan ruang untuk menilai pemulihan kerugian dan pemaafan korban terhadap pelaku dalam lingkup perdamaian sesuai nilai Pancasila yaitu permusyawaratan dalam kebijaksanaan pemidanaan.

Muladi menjelaskan bahwa hakikat tujuan pemidanaan dalam konteks Pancasila, yang pertama-tama harus dihayati adalah pendekatan multi dimensional yang bersifat mendasar terhadap dampak tindak pidana. Dengan demikian tujuan pemidanaan adalah untuk memperbaiki kerusakan baik yang bersifat individual, maupun yang bersifat sosial (individual and social damages) yang diakibatkan oleh tindak pidana. ${ }^{6}$ Dalam kerangka ini, maka tujuan pemidanaan harus berorientasi pada pandangan yang integratif, yang terdiri dari seperangkat tujuan pemidanaan yang harus dipenuhi, dengan catatan bahwa tujuan manakah yang merupakan titik berat sifatnya kasuistis. Dalam tujuan pemidanaan pula tercakup tujuan memelihara solidaritas masyarakat. Pemidanaan harus diarahkan untuk memelihara dan mempertahankan kesatuan masyarakat (to maintain social cohasion intact).

Berkaitan dengan konteks perdamaian berdasarkan permusyawaratan dan kebijaksanaan dalam tujuan pemidanaan diatas maka sudah seharusnya bahwa tidak saja menjadi alasan peringanan pidana saja, tetapi dapat berupa penghapusan pemidanaan bilamana telah terpulihkannya kerugian korban dan akibat terganggunya sosial dari tindak pidana telah pula diharmonisasikan kembali. Dengan demikian pembaruan hukum pidana nasional telah memberikan penegasan akan sebuah upaya refilosofi pemidanaan dari

6 Muladi, 1995, Kapita Selekta Sistem Peradilan Pidana, Badan Penerbit Universitas Diponegoro, Semarang, hal.30 retributive justice menuju restorative justice. Orientasi penghukuman sejauh mungkin dapat bermanfaat bagi para pihak (dalam hal ini Korban, Pelaku dan masyarakat) guna pemulihan konflik di masa yang akan datang. Oleh karenanya output dari proses peradilan ini adalah tetap berlandaskan pada penyelesaian konflik dan pemulihan hubungan antar pihak. Dengan demikian tindak pidana dipersepsikan sebagai pelanggaran terhadap hak-hak individu (korban) oleh individu yang lain (Pelaku) dalam masyarakat, sehingga penyelesaiannya pun diorientasikan pada pemulihan hubungan.

\section{B. Jenis Tindak Pidana Yang Diselesaikan Di Luar Mekanisme Hukum Pidana}

Dalam Hukum Positif Indonesia perkara pidana tidak dapat diselesaikan diluar proses pengadilan, akan tetapi dalam hal-hal tertentu dimungkinkan pelaksanaanya. Dalam praktiknya penegakan hukum pidana di Indonesia, walaupun tidak ada landasan hukum formalnya perkara pidana sering diselesaikan diluar proses pengadilan melalui diskresi aparat penegak hukum, mekanisme perdamaian, lembaga adat dan sebagainya. Konsekuensi makin diterapkan eksistensi mediasi penal sebagai salah satu alternatif penyelesaian perkara dibidang hukum pidana melalui restitusi dalam proses pidana menunjukkan, bahwa perbedaan antara hukum pidana dan perdata tidak begitu besar dan perbedaan itu menjadi tidak berfungsi. ${ }^{7}$ Mediasi Penal yang menerapkan nilai-nilai keadilan restoratif bukanlah barang baru bagi masyarakat Indonesia, malahan sekarang keadilan ini dikatakan sebagai pendekatan yang Progresif seperti yang disampaikan

${ }^{7}$ Barda Nawawi Arief, 2008, Mediasi Penal Penyelesaian Perkara Diluar Pengadilan, Pustaka Magister, Semarang, hal.4 
oleh Marc Levin "Pendekatan yang dulu dinyatakan usang, kuno dan tradisional dikatakan sebagai pendekatan yang progresif". ${ }^{8}$ Menurut Barda Nawawi Arief, Alasan dipergunakan mediasi penal dalam penyelesaian perkara pidana adalah karena ide dari mediasi penal berkaitan dengan masalah pembaharuan hukum pidana (Penal Reform), berkaitan juga dengan masalah pragmatisme, alasan lainnya adalah adanya ide perlindungan korban, ide harmonisasi, ide restorative justice, ide mengatasi kekakuan (formalitas) dan efek negatif dari sistem peradilan pidana dan sistem pemidanaan yang berlaku, serta upaya pencarian upaya alternatif pemidanaan (selain penjara). ${ }^{9}$

Sebenarnya dalam masyarakat Indonesia penyelesaian suatu perkara baik perdata maupun pidana dengan Mediasi Penal bukan hal baru, hal ini dibuktikan dengan adanya penyelesaian dengan pendekatan musyawarah. Bila dilihat secara histories kultur (budaya) masyarakat Indonesia sangat menjunjung tinggi pendekatan konsensus, yang lebih mengutamakan pengambilan keputusan secara tradisional dan penyelesaian melalui mekanisme adat. ${ }^{10}$ Mudzakkir mengemukakan beberapa kategorisasi sebagai tolak ukur dan ruang lingkup terhadap perkara yang dapat diselesaikan di luar pengadilan melalui mediasi penal adalah sebagai berikut: ${ }^{11}$

a. Pelanggaran hukum pidana tersebut memiliki pidana denda sebagai ancaman pidana dan pelanggar telah

\footnotetext{
${ }^{8}$ Marc Levin dalam Eva Achjani Zulfa, 2011, Pergeseran Paradigma Pemidanaan, Lubuk Agung, Bandung, hal.67

${ }^{9}$ Barda Nawawi, Op.Cit, hal.169

10 Mushadi, 2007, Mediasi dan Resolusi Konflik di Indonesia, Walisongo Mediator Center, Semarang, hal.38

11 Mudzakkir, 2013, Mediasi Penal Penerapan Nilai-Nilai Restoratif Justice dalam penyele- saian tindak pidana adat bali, tesis, fakultas hukum Universitas Indonesia, Jakarta, hal.55
}

membayar denda tersebut (Pasal 80 KUHP);

b. Pelanggaran hukum pidana tersebut termasuk kategori "pelanggaran", bukan "kejahatan", yang hanya diancam dengan pidana denda;

c. Pelanggaran hukum pidana tersebut termasuk tindak pidana di bidang hukum administrasi yang menempatkan sanksi pidana sebagai ultimum remedium;

d. Pelanggaran hukum pidana tersebut termasuk kategori ringan/serba ringan dan aparat penegak hukum menggunakan wewenangnya untuk melakukan diskresi;

e. Pelanggaran hukum pidana biasa yang dihentikan atau tidak diproses ke pengadilan oleh Jaksa Agung sesuai dengan wewenang hukum yang dimilikinya;

f. Pelanggaran hukum pidana tersebut termasuk kategori pelanggaran hukum pidana adat yang diselesaikan melalui lembaga adat.

Salah satu upaya penerapan keadilan restoratif yang dapat dilakukan oleh kepolisian dalam memaksimalkan penyelesaian dengan menggunakan mekanisme mediasi Penal. Penyelesaian perkara-perkara ini dapat dilakukan oleh kepolisian selaku garda utama sistem peradilan pidana, dengan kewenangannya yaitu diskresinya dalam menyelesaikan suatu perkara pidana perlindungan konsumen. Bahkan pelaksanaan nilai-nilai keadilan restoratif oleh aparat kepolisian telah diberikan suatu dasar hukum berupa Surat telegram rahasia Kabareskrim Kepolisian Negara Republik Indonesia No: STR/583/VII/2012 Tanggal 8 Agustus 2012. 


\section{Implikasi Penggunaan Mekanisme Di Luar Sistem Hukum Pidana}

Penyelesaian perkara pidana di luar peradilan dengan bentuknya seperti penyelesaian secara adat, penyelesaian secara kekeluargaan atau melalui mediasi, yang difasilitasi oleh penyidik, merupakan fenomena yang umum terjadi di berbagai daerah di Indonesia. Dalam praktiknya, perkara diselesaikan secara musyawarah yang dimediasi oleh penyidik. Setelah diperoleh kesepakatan, korban mengajukan penarikan laporan ke penyidik, kemudian penyidik mengeluarkan surat perintah penghentian penyidikan (SP3) dengan alasan tidak cukup bukti, sehingga perkara tidak dilanjutkan. Cara penyelesaian perkara pidana seperti ini barangkali dapat memenuhi tuntutan keadilan dan kemanfaatan, namun bisa menjadi persoalan jika dilihat dari aspek legalitas dan kepastian hukum. Cara penyelesaian yang demikian juga menimbulkan pertanyaan, apakah dapat disebut sebagai mediasi penal. ${ }^{12}$

Dalam konteks penyelesaian perkara pidana, mediasi penal merupakan penyelesaian perkara pidana melalui musyawarah dengan bantuan mediator yang netral, dihadiri korban dan pelaku beserta orang tua dan perwakilan masyarakat, dengan tujuan pemulihan bagi korban, pelaku, dan lingkungan masyarakat. Menurut Sahuri Lasmadi, prinsip-prinsip yang terkandung di dalam mediasi penal adalah, pertama, perlu adanya seorang mediator dalam penanganan konflik. Mediator haruslah seorang yang dapat meyakinkan para pihak yang terlibat dalam konflik dengan mengedepankan proseskomunikasi. Kedua, mengutamakan

12 Usman dan Andi Najemi, 2018, Mediasi Penal di Indonesia: Keadilan, Kemanfaatan, dan Kepastian Hukumnya, Jurnal Hukum Vol.01 No.01 Tahun 2018, Fakultas Hukum Universitas Jambi, hal.67 kualitas proses. Dalam mediasi perlu ditekankan intensitas dan kualitas proses, bukan pada menang atau kalah. Proses diarahkan untuk membangun kesadaran masing-masing pihak untuk saling menghargai sehingga tercapai win-win solution. Ketiga, proses bersifat informal. Mediasi penal merupakan suatu proses yang informal, tidak bersifat birokratis, menghindari prosedur hukum yang ketat, sehinga para pihak yang terlibat merasa dihargai. Keempat, semua terlibat dalam proses. Para pihak (pelaku dan korban) tidak dilihat sebagai objek dari prosedur hukum pidana, tetapi lebih sebagai subjek yang mempunyai tanggung jawab pribadi dan kemampuan untuk berbuat para pihak ditanamkan budaya malu dan budaya saling memaafkan, dengan tujuan jika proses mediasi telah berhasil semua pihak tidak merasa dipermalukan. ${ }^{13}$

Hal ini menunjukkan bahwa mediasi penal itu bersifat fleksibel, baik mengenai prosesnya maupun para pihak yang terlibat di dalamnya. Hal ini tentunya sesuai dengan prinsip-prinsip serta filosofi yang mendasari penyelesaian perkara melalui mediasi penal, yang pada dasarnya bermuara pada tercapainya kesepakatan di antara para pihak yang didasarkan pada win-win solution, sehingga tercipta kedamaian dan harmoni di dalam masyarakat.

Kelemahan peradilan pidana berkaitan dengan posisi korban dalam sistem peradilan pidana. Korban kejahatan mempunyai posisi yang sangat lemah dalam sistem peradilan pidana (criminal justice system) karena ia hanya dapat berperan sebagai saksi (korban) untuk mengungkap kebenaran terjadinya tindak pidana yang mengorbankan dirinya. Dengan peran tersebut saksi korban diminta untuk

13 Sahuri Lasmadi, 2011, Mediasi Dalam Sistem Peradilan Pidana Indonesia, Makalah disampaikan dalam lokakarya hakim, Jambi, hal.7 
memberi kesaksian mengenai apa yang ia lihat, yang ia dengar, yang ia alami dan yang ia rasakan di seputar kejahatan yang menimpanya.

Kesaksian korban kejahatan dalam proses peradilan pidana tidak dimaksudkan untuk membela kepentingan dan hakhaknya yang telah dilanggar oleh pelaku kejahatan, melainkan hanya untuk membantu tugas jaksa dalam upaya pembuktian. Penuntutan hukum terhadap pelaku kejahatan juga bukan untuk dan atas nama korban, tapi untuk dan aas nama masyarakat dan/atau negara. Keadilan yang ingin ditegakkan pengadilan bukan keadilan untuk korban, melainkan keadilan untuk masyarakat dan pelaku tindak pidana. dengan menegakkan keadilan bagi masyarakat secara tidak langsung juga diharapkan adanya keadilan bagi korban kejahatan.

Korban kejahatan tidak punya peran sama sekali dalam menentukan berat ringannya tuntutan hukum yang diajukan oleh jaksa dan dalam menentukan berat ringannya pidana patut dijatuhkan hakim terhadap pelaku kejahatan. Tidak ada forum yang tersedia bagi korban untuk mengungkapkan pendapatnya tentang bagaimana seharusnya tuntutan hukum dibuat oleh jaksa dan bagaimana seharusnya pidana dijatuhkan hakim terhadap pelaku kejahatan.

Karena ada kelemahan dan ketidakpuasan terhadap operasionalisasi sistem peradilan pidana, maka ada dorongan untuk mencari penyelesaian sengketa alternatif dari sistem peradilan pidana yang ada. Mediasi penal merupakan salah satu instrumen alternatif penyelesaian sengketa di luar sistem atau menjadi bagian sistem peradilan pidana.

Implikasi penggunaan mekanisme di luar sistem hukum pidana baik bagi korban maupun pelaku dapat dijelaskan bahwa korban diakui keberadaannya dan dianggap sebagai pihak yang menentukan dalam penyelesaian suatu perkara pidana. dalam prinsip dasar yang ditentukan bahwa korban didudukan sebagai pihak yang langsung berdialog dengan pelaku dalam kerangka mencari kebaikan terutama kepada kedua pihak disamping kepada masyarakat. Berbeda dengan sistem peradilan pidana dimana pelaku bukan berhadapan dengan korban melainkan dengan negara. Demikian halnya dengan pelaku diberikan kesempatan untuk mewujudkan suatu bentuk pertanggungjawaban secara langsung kepada korban seperti penggantian biaya akibat yang diperbuat oleh pelaku terhadap korban. Bentuk pertanggungjawaban pelaku secara langsung ditujukan untuk memulihkan keadaan yang buruk sebagai akibat dari tindak pidana yang dilakukannya. Dalam sistem peradilan pidana maupun diluar sistem peradilan pidana memberikan kewajiban untuk mengarahkan bentuk penyelesaian ke arah kondisi pemulihan kepada pihak atau lembaga yang menangani perkara pidana itu.

Dalam hal penyelesaian perkara pidana melalui cara mediasi di tingkat pengadilan, hakim memandang penyelesaian tersebut dapat dijadikan dasar pertimbangan yang meringankan pidana daripada pelaku karena hakim tidak memiliki landasan hukum untuk menjadikan suatu penyelesaian perkara pidana dengan perdamaian sebagai hal yang dapat menghapus pertanggungjawaban pidana.

PERSEPSI SOSIAL, KORBAN DAN PENEGAK HUKUM DALAM MENILAI ALASAN PENIADAAN PERTANGGUNGJAWABAN HUKUM ATAS HILANGNYA JIWA MANUSIA DENGAN KUALIFIKASI CULPA LATA (BEWUSTE SCHULD) DAN DOLUS EVENTUALIS 


\section{A. Persepsi Sosial Dari Kasus Penghentian Tindak Pidana}

Di Indonesia, Kalimantan Timur adalah salah satu dari Provinsi utama penghasil batubara, pada masa Orde Baru, sebelum masa otonomi daerah, ijin tambang di Kalimantan Timur meliputi 69 Ijin Kuasa Pertambangan (KP), 9 Ijin Kontrak Karya (KK) dan 40 Ijin Perjanjian Karya pengusahaan Pertambangan Batubara (PKP2B), dengan total ijin adalah 118 buah. Jumlah ijin ini meningkat hampir 13 kali lipat pada masa otonomi daerah menjadi 1.488 Ijin Usaha Pertambangan. ${ }^{14}$

Kota Samarinda tak luput dari incaran perusahaan tambang batubara. Data distamben 2008, luas IUP di Samarinda adalah 24.933,5 hektar dan luas KP Pusat sebesar 22.839 hektar. Bila ditotal jumlahnya mencapai 66,5 persen dari luas Samarinda yaitu 71.800 hektar. Sementara, menurut versi jatam hingga Desember 2008, luas KP di Samarinda seluas 27,549.66 hektar (38,37\%), KP Pusat seluas 2,343.00 hektar (3,26\%) dan PKP2B sebesar 20,843.10 hektar (29,03\%). Jika ditotal luasnya 50,735.76 hektar atau sekitar $71 \%$ luasan Samarinda. ${ }^{15}$ Akibat dari banyaknya izin tambang batubara yang dikeluarkan tersebut menimbulkan berbagai permasalahan di dalam masyarakat yaitu salah satunya penambangan di kawasan daerah padat pemukiman penduduk yang dimana perusahaan banyak melakukan penambangan dengan sistem terbuka (open pit mine) sehingga menyebabkan banyak meninggalkan lubang-lubang pasca tambang $^{16}$ yang berbahaya. Komisi

${ }^{14}$ Basyir Daud, 2017, Samarinda Menggugat; ketika kegelisahan menjadi kemarahan, Jaringan Advokasi Tambang (JATAM), Jakarta, hal.3

${ }^{15} \mathrm{Ibid}$, hal.5

${ }^{16}$ Kegiatan pasca tambang, yang selanjutnya disebut pasca tambang, adalah kegiatan terencana, sistematis, dan berlanjutan setelah akhir sebagian atau seluruh kegiatan usaha pertambangan untuk memulihkan fungsi lingkungan alam dan fungsi sosial menurut kondisi lokal di seluruh wilayah
Nasional Hak Asasi Manusia menerima banyak aduan mengenai perusahaan tambang di Kalimantan Timur yang mengabaikan lubang tambang yang berbahaya bagi masyarakat setempat karena jarak yang terlalu dekat dengan pemukiman. Lubang hasil galian perusahaan tambang sejak 2011 sampai 2017 menyebabkan 28 korban meninggal dalam lubang pascatambang. ${ }^{17}$ penambangan (Pasal 1 angka 27 Undang-Undang Nomor 4 Tahun 2009 tentang Pertambangan Mineral Dan Batubara)

${ }^{17} \mathrm{https} / / /$ www.jatam.org/2017/07/05/lagilubang-maut-batu-bara-makan-korba $\mathrm{n} /$ diakses pada tanggal 30 Juli 2017, Pukul 20.06 Wita 
Tabel 1. Daftar Korban meninggal di Tambang Kalimantan Timur 2011-2017

\begin{tabular}{|c|c|c|c|c|c|}
\hline No & Korban & Perusahaan & Lokasi & $\begin{array}{c}\text { Waktu } \\
\text { Kejadian }\end{array}$ & Wilayah \\
\hline 1 & $\begin{array}{l}\text { Muhammad } \\
\text { Fariqi (14 thn) }\end{array}$ & PT.Kitadin & $\begin{array}{c}\text { Desa Bangun } \\
\text { Rejo } \\
\text { Kec.Tenggarong } \\
\text { Seberang }\end{array}$ & $\begin{array}{c}26 \text { Januari } \\
2012\end{array}$ & Kukar \\
\hline 2 & $\begin{array}{l}\text { Sanofa M Rian } \\
\text { (14 thn) }\end{array}$ & $\begin{array}{c}\text { PT.Bara Sigi } \\
\text { Mining } \\
\text { (BSM) }\end{array}$ & $\begin{array}{c}\text { Desa Sebulu } \\
\text { Modern, RT.14 } \\
\text { Jalan Poros } \\
\text { Tenggarong- } \\
\text { Sebulu }\end{array}$ & $\begin{array}{c}05 \text { Agustus } \\
2015\end{array}$ & Kukar \\
\hline 3 & $\begin{array}{l}\text { Budi Maulana } \\
\text { (11 thn) }\end{array}$ & $\begin{array}{l}\text { PT.Muliana } \\
\text { Jaya }\end{array}$ & $\begin{array}{c}\text { Kelurahan Jawa } \\
\text { Rt.4 Kecamatan } \\
\text { Sangasanga }\end{array}$ & $\begin{array}{l}05 \text { Agustus } \\
2015\end{array}$ & Kukar \\
\hline 4 & $\begin{array}{l}\text { Mulyadi (15 } \\
\text { thn) }\end{array}$ & $\begin{array}{c}\text { PT.Mulia } \\
\text { Harapan } \\
\text { Utama (MHU) }\end{array}$ & $\begin{array}{c}\text { Kelurahan Loa } \\
\text { Ipuh Darat Rt.3 } \\
\text { Kecamatan } \\
\text { Tenggarong }\end{array}$ & $\begin{array}{c}16 \\
\text { Desember } \\
2015\end{array}$ & Kukar \\
\hline 5 & $\begin{array}{l}\text { Dewi Ratna (9 } \\
\text { thn) }\end{array}$ & $\begin{array}{c}\text { KSU Wijaya } \\
\text { Kusuma }\end{array}$ & $\begin{array}{c}\text { Desa Sumber } \\
\text { Sari kec.Sebulu }\end{array}$ & $\begin{array}{c}30 \\
\text { Desember } \\
2015 \\
\end{array}$ & Kukar \\
\hline 6 & $\begin{array}{l}\text { Noval Fajar } \\
\text { Slamat Riyadi } \\
\text { (15 thn) }\end{array}$ & $\begin{array}{c}\text { PT.Bukit } \\
\text { Baiduri Energi }\end{array}$ & $\begin{array}{c}\text { Desa Bukit Raya } \\
\text { Rt.19 } \\
\text { Kec.Tenggarong } \\
\text { Seberang }\end{array}$ & $\begin{array}{c}23 \text { Maret } \\
2016\end{array}$ & Kukar \\
\hline 7 & $\begin{array}{l}\text { Diky Aditya (15 } \\
\text { thn) }\end{array}$ & $\begin{array}{c}\text { PT.Bukit } \\
\text { Baiduri Energi }\end{array}$ & $\begin{array}{c}\text { Desa Bukit Raya } \\
\text { Rt.19 } \\
\text { Kec.Tenggarong } \\
\text { Seberang }\end{array}$ & $\begin{array}{l}23 \text { Maret } \\
2016\end{array}$ & Kukar \\
\hline 8 & $\begin{array}{l}\text { Tidak } \\
\text { Teridentifikasi }\end{array}$ & PT.Kitadin & $\begin{array}{l}\text { Tenggarong } \\
\text { Seberang }\end{array}$ & 2011 & Kukar \\
\hline 9 & Wilson (17 thn) & $\begin{array}{c}\text { PT.Insani } \\
\text { Bara Perkara }\end{array}$ & $\begin{array}{c}\text { Desa Purwajaya } \\
\text { Rt.18 } \\
\text { Kec.Loajanan }\end{array}$ & $\begin{array}{l}15 \text { Mei } \\
2016\end{array}$ & Kukar \\
\hline 10 & $\begin{array}{l}\text { Miftahul Jannah } \\
\text { (10 thn) }\end{array}$ & $\begin{array}{c}\text { PT.Hymco } \\
\text { Coal }\end{array}$ & $\begin{array}{l}\text { Sungai Kerbau, } \\
\text { Kec.Sambutan }\end{array}$ & $\begin{array}{l}\text { 13 Juli } \\
2011\end{array}$ & Samarinda \\
\hline 11 & Junaidi (13 thn) & $\begin{array}{c}\text { PT.Hymco } \\
\text { Coal }\end{array}$ & $\begin{array}{l}\text { Sungai Kerbau, } \\
\text { Kec.Sambutan }\end{array}$ & $\begin{array}{l}\text { 13 Juli } \\
2011\end{array}$ & Samarinda \\
\hline 12 & Ramadhani & $\begin{array}{c}\text { PT.Hymco } \\
\text { Coal }\end{array}$ & $\begin{array}{l}\text { Sungai Kerbau, } \\
\text { Kec.Sambutan }\end{array}$ & $\begin{array}{c}\text { 13 Juli } \\
2011\end{array}$ & Samarinda \\
\hline 13 & $\begin{array}{l}\text { Dede } \\
\text { Rahmad/Eza (6 }\end{array}$ & $\begin{array}{c}\text { PT.Panca } \\
\text { Prima Mining }\end{array}$ & $\begin{array}{c}\text { Sambutan } \\
\text { Idaman Permai, }\end{array}$ & $\begin{array}{c}24 \\
\text { Desember }\end{array}$ & Samarinda \\
\hline
\end{tabular}




\begin{tabular}{|c|c|c|c|c|c|}
\hline & thn) & & Pelita 2 & 2011 & \\
\hline 14 & $\begin{array}{l}\text { Emaliya Raya } \\
\text { Dinata/Ema }(6 \\
\text { thn })\end{array}$ & $\begin{array}{c}\text { PT.Panca } \\
\text { Prima Mining }\end{array}$ & $\begin{array}{c}\text { Sambutan } \\
\text { Idaman Permai, } \\
\text { Pelita } 2\end{array}$ & $\begin{array}{c}24 \\
\text { Desember } \\
2011\end{array}$ & Samarinda \\
\hline 15 & $\begin{array}{c}\text { Maulana } \\
\text { Mahendra (11 } \\
\text { thn) }\end{array}$ & $\begin{array}{l}\text { PT.Insani bara } \\
\text { Perkasa }\end{array}$ & $\begin{array}{l}\text { Simpang Pasir, } \\
\text { Palaran }\end{array}$ & $\begin{array}{c}25 \\
\text { Desember } \\
2012\end{array}$ & Samarinda \\
\hline 16 & $\begin{array}{c}\text { M.Shendy (8 } \\
\text { thn) }\end{array}$ & $\begin{array}{c}\text { Tak } \\
\text { teridentifikasi }\end{array}$ & $\begin{array}{l}\text { Kel.Sambutan, } \\
\text { Pelita } 4\end{array}$ & $\begin{array}{l}\text { 14 Maret } \\
2013\end{array}$ & Samarinda \\
\hline 17 & $\begin{array}{l}\text { Nadia Zaskia } \\
\text { Putri (10 thn) }\end{array}$ & $\begin{array}{l}\text { PT.Energy } \\
\text { Cahaya } \\
\text { Industritama }\end{array}$ & $\begin{array}{c}\text { Kel.Rawa } \\
\text { Makmur, Palaran }\end{array}$ & $\begin{array}{l}08 \text { April } \\
2014\end{array}$ & Samarinda \\
\hline 18 & $\begin{array}{c}\text { M Raihan } \\
\text { Saputra (10 thn) }\end{array}$ & $\begin{array}{l}\text { PT.Graha } \\
\text { Benua Etam }\end{array}$ & Sempaja & $\begin{array}{c}22 \\
\text { Desember } \\
2014 \\
\end{array}$ & Samarinda \\
\hline 19 & $\begin{array}{c}\text { Ardi Bin } \\
\text { Hasyim (13 thn })\end{array}$ & $\begin{array}{l}\text { PT.Cahaya } \\
\text { Energi } \\
\text { Mandiri } \\
\end{array}$ & $\begin{array}{l}\text { Kel.Sambutan, } \\
\text { Pelita } 7\end{array}$ & $\begin{array}{c}23 \mathrm{Mei} \\
2015\end{array}$ & Samarinda \\
\hline 20 & $\begin{array}{c}\text { Muhammad } \\
\text { Yusuf Subhan } \\
(11 \text { thn })\end{array}$ & $\begin{array}{c}\text { PT.Lana } \\
\text { Harita } \\
\text { Indonesia }\end{array}$ & Sungai Siring & $\begin{array}{l}24 \text { Agustus } \\
2015\end{array}$ & Samarinda \\
\hline 21 & $\begin{array}{c}\text { Aprillia } \\
\text { Wulandari (12 } \\
\text { thn) }\end{array}$ & $\begin{array}{l}\text { PT.Transisi } \\
\text { Energi } \\
\text { Satunama }\end{array}$ & Lok Bahu & $\begin{array}{c}18 \\
\text { November } \\
2015\end{array}$ & Samarinda \\
\hline 22 & $\begin{array}{l}\text { Koko Handoko } \\
\text { (16 thn) }\end{array}$ & $\begin{array}{l}\text { CV.Atap Tri } \\
\text { Utama }\end{array}$ & Bantuas, Palaran & $\begin{array}{l}\text { 03 Mei } \\
2016\end{array}$ & Samarinda \\
\hline 23 & $\begin{array}{c}\text { Kusmayadi (22 } \\
\text { thn) }\end{array}$ & $\begin{array}{c}\text { CV.Panca } \\
\text { Bara Sejahtera }\end{array}$ & Samarinda Ulu & $\begin{array}{c}03 \mathrm{Mei} \\
2016\end{array}$ & Samarinda \\
\hline 24 & $\begin{array}{l}\text { Edy Kurniawan } \\
\quad(15 \text { thn })\end{array}$ & $\begin{array}{c}\text { PT.Energy } \\
\text { Cahaya } \\
\text { Industritama }\end{array}$ & Bukuan, Palaran & $\begin{array}{c}08 \\
\text { November } \\
2016\end{array}$ & Samarinda \\
\hline 25 & $\begin{array}{l}\text { Dias Mahendra } \\
\quad(15 \text { thn })\end{array}$ & $\begin{array}{c}\text { PT.Energy } \\
\text { Cahaya } \\
\text { Industritama }\end{array}$ & Bukuan, Palaran & $\begin{array}{c}08 \\
\text { November } \\
2016\end{array}$ & Samarinda \\
\hline 26 & $\begin{array}{l}\text { M Arham (5 } \\
\text { thn) }\end{array}$ & $\begin{array}{c}\text { PT.Insani } \\
\text { Bara Perkasa }\end{array}$ & Palaran & $\begin{array}{c}06 \mathrm{Mei} \\
2016\end{array}$ & Samarinda \\
\hline 27 & $\begin{array}{c}\text { Agus Irawan } \\
\text { (20 thn) }\end{array}$ & $\begin{array}{c}\text { PT.Bumi } \\
\text { Energi Kaltim }\end{array}$ & $\begin{array}{l}\text { Buluminung, } \\
\text { Penajam }\end{array}$ & $\begin{array}{l}\text { 12 Februari } \\
2016\end{array}$ & $\begin{array}{c}\text { Penajam Paser } \\
\text { Utara }\end{array}$ \\
\hline 28 & $\begin{array}{l}\text { Novita Sari } \\
\text { (18 thn) }\end{array}$ & $\begin{array}{c}\text { PT.Gunung } \\
\text { Bayan } \\
\text { Pratama Coal }\end{array}$ & $\begin{array}{c}\text { Desa Belusuh, } \\
\text { Kec. Siluaq } \\
\text { Ngurai }\end{array}$ & $\begin{array}{l}25 \text { Juni } \\
2017\end{array}$ & Kutai Barat \\
\hline
\end{tabular}

Sumber : Komisi Nasional Hak Asasi Manusia Republik Indonesia, 2016, Pelanggaran Hak Asasi Manusia dalam kasus eks lubang tambang batubara di Kalimantan Timur 
Eksistensi dari penyelesaian perkara di luar jalur pengadilan atau sering disebut dengan mediasi penal mengandung asas diterapkannya solusi menang-menang (winwin solution). Diharapkan melalui proses mediasi penal ini dapat terjadinya kesepakatan antara para pihak baik pelaku maupun korban. Para pihak diharapkan dapat mencari dan mencapai solusi serta alternatif terbaik untuk menyelesaikan perkara tersebut. Implikasi dari pencapaian tersebut, pihak pelaku dan korban dapat mengajukan kompensasi yang ditawarkan, disepakati dan dirundingkan antara mereka bersama sehingga solsui yang dicapai bersifat win-win solution. Dilihat dari segi sosial maka aspek ini berorientasi pada masyarakat Indonesia pada nilai budaya kekeluargan, mengedapankan asas musyawarah mufakat untuk menyelesaikan suatu sengketa dalam suatu sistem sosial. Tegasnya aspek dan dimensi tersebut diselesaikan melalui dimensi kearifan lokal hukum adat sebagaimana merupakan pencerminan dari kesadaran hukum rakyat Indonesia. Kearifan lokal hukum adat merupakan suatu hukum yang hidup karena ia menjelmakan perasaan hukum yang nyata dari rakyat, serta berkembang sejalan dengan perkembangan masyarakatnya.

Dalam hal peradilan pidana sebagai kontrol sosial formal yang melembaga tidak memperhatikan penderitaan dari korban kejahatan, baik berupa penderitaan fisik maupun mental, maupun penderitaan sosial dan ekonomis. Korban di lupakan dan diabaikan oleh para penegak hukum, penuntut umum, pengadilan dan pembinaan pemasyarakatan. Penderitaan korban tidak akan dijadikan pertimbangan oleh jaksa dalam melakukan penuntutan dan hakim dalam menjatuhkan pidana terhadap pelaku kejahatan.

Praktik peradilan sering kali tidak memuaskan bagi korban bukan karena pelaku kejahatan yang merugikan dirinya dibebaskan oleh pengadilan atau hukuman yang dijatuhkan hakim tidak sebanding dengan penderitaan yang dialami oleh korba maupun keluarga korban. Akan tetapi, juga akibat perlakuan yang diterima korban dari apartur peradilan pidana yang adakalanya tidak memberikan keadilan bagi para korban, sering ditemui bahwa pada tahap penyidikan di kepolisian justru korban ataupun keluarga korban diintimidasi karena keberpihakan penyidik kepada pihak yang dianggap menguntungkan dalam proses pemeriksaan. Sehingga dengan adanya kelemahan dan ketidakpuasan para pihak yang berpekara di dalam sistem peradilan pidana tersebut, maka ada dorongan untuk menari penyelesaian sengketa alternatif dari sistem peradilan pidana, salah satunya adalah dengan dilakukannya mediasi penal tersebut. Dari hasil penelitian yang dilakukan oleh penulis terkait persepsi sosial terhadap dalam hal penghentian tindak pidana tersebut bahwa korban pada pihak yang lemah sehingga tidak memiliki kemampuan baik dari segi pengetahuan hukum dan finansial di bandingkan dengan perusahaan pada pihak yang kuat sehingga masyarakat tidak dapat berbuat apa-apa selain berharap kasus yang terjadi dapat diselesaikan oleh penegak hukum seadiladilnya.

Pendapat penulis bahwa pada tahap penyidikan maupun penyelidikan dalam menangani kasus pidana tersebut tentu memiliki dasar hukum yang jelas yakni berdasarkan alat bukti yang ada, apabila tidak ditemukannya alat bukti yang cukup maka penyidik dalam hal ini pihak kepolisian tidak dapat berbuat banyak selain memberikan solusi perdamaian. karena hal ini tentunya berkaitan dengan rasa keadilan dan kepastian hukum bagi para pihak baik itu pelaku maupun korban. Sehingga diharapkan dengan dilakukannya mediasi penal untuk mencapai suatu 
kesepakatan dapat memberikan keuntungan bagi kedua belah pihak yaitu dengan adanya win-win solution. Tentunya dari segi sosial seharusnya tidak mempermasalahkan tentang penghentian tindak pidana tersebut apalagi terhadap kemanfaatan bagi kedua belah pihak dalam menyelesaikan permasalahan yang ada. Karena fungsi dari hukum itu sendiri selain memberikan keadilan dan kepastian hukum namun juga harus mempertimbangkan kemanfaatan bagi semua pihak dan juga termasuk masyarakat. Sehingga dalam hal ini memberikan peran masyarakat yang lebih luas dalam menentukan keberhasilan penyelesaian sengketa di luar sistem peradilan pidana.

\section{B. Persepsi Korban Dari Kasus Penghentian Tindak Pidana}

Berkaitan dengan kasus meninggalnya seseorang di lubang tambang, penulis telah melakukan wawancara dengan beberapa keluarga korban yang berlokasi di Samarinda, spesifiknya adalah daerah Kelurahan Sambutan, Kecamatan Sambutan yang mana terdapat 6 (enam) korban pada konsensi lahan yang dikerjakan oleh PT.Hymco Coal dan PT. Panca Prima Mining yaitu:

1. Miftahul Jannah (10 Tahun);

2. Junaidi (13 Tahun);

3. Ramadhani (13 Tahun);

4. Dede Rahmad (6 Tahun);

5. Emaliya Raya Dinata (6 Tahun);

6. Ardi Bin Hasyim (13 Tahun).

Pada tangal 13 Juli 2011 terjadi peristiwa kematian 3 (tiga) orang anak bernama miftahul jannah (mimi), Junaidi (juned) dan Ramadhani (rahmad) yang masih bersaudara tenggelam di lubang bekas tambang PT.Hymco Coal di kecamatan Sambutan, Kota Samarinda. Tidak ada kejelasan hukum kepada orang tua korban terkait kasus anak-anak mereka tersebut sampai pada saat wawancara ini dilakukan. Pemerintah beserta perusahaan hanya bertanggung jawab dengan memberikan uang tali asih sebesar Rp.15.000.000,- (lima belas juta rupiah). salah satu keluarga dari korban bekerja di perusahaan pertambangan batu bara tersebut tidak ingin melanjutkan kasus ini ke jalur hukum karena tidak ingin kehilangan pekerjaannya di perusahaan tambang tersebut. ${ }^{18}$

Pendapat penulis dalam hal ini bahwa keluarga korban tidak memiliki pengetahuan hukum yang cukup dan karena alasan faktor ekonomi sehingga mereka memilih untuk tidak memperkarakan hal ini lebih lanjut. Apalagi tidak adanya dukungan dari pemerintah dalam membantu penyelesaian perkara ini sehingga memilih untuk menerima apa yang ditawarkan oleh pihak perusahaan.

Pada tanggal 24 Desember 2011, 2 (dua) anak atas nama Emaliya Raya Dinata (ema) dan Dede Rahmad (eza) meninggal di lubang tambang milik PT. Panca Prima Mining di kecamatan Sambutan, Kota Samarinda. Sebagaimana telah dijelaskan sebelumnya bahwa kasus ini pernah di bawa ke jalur hukum sampai diputuskan oleh Pengadilan Negeri Samarinda pada tanggal 28 Januari 2013. Selain daripada itu, keluarga juga mendapatkan uang tali asih sebesar Rp.100.000.000,- (seratus juta rupiah) dari perusahaan. ${ }^{19}$

Pendapat penulis bahwa walaupun dalam hal ini ada pihak yang telah menerima hukuman tetapi tidak

${ }^{18}$ Hasil wawancara dengan orang tua korban Bapak Amat di rumah kediamannya di Pelita IV Sambutan pada tanggal 3 Maret 2018 pada pukul 10.00 wita

19 Hasil wawancara dengan paman korban ema dan eza di Pelita VII kelurahan sambutan Samarinda, pada tanggal 3 Maret 2018, pukul 13.00 wita 
memberikan rasa keadilan bagi keluarga korban, karena yang menerima sanksi bukan kapasitas mewakili perusahaan dalam hal ini direktur perusahaan melainkan adalah wakar penjaga tambang dengan hukuman selama 3 (tiga) bulan penjara.

Kemudian pada tanggal 25 Mei 2015 terjadi kasus serupa terhadap korban Ardi bin Hasyim yang memiliki kebutuhan khusus di lubang bekas tambang milik PT. Cahaya Energi Mandiri. Korban ditemukan setelah 3 (tiga) hari hilang dari Pihak keluarga korban tidak mau dilakukan visum et reperteum karena keluarga korban menganggap bahwa kematian dari anak mereka merupakan musibah sehingga tidak ingin memproses kasus ini lebih lanjut ke jalur hukum. Sehingga pihak kepolisian juga kesulitan dalam mengumpulkan alat bukti yang diperlukan. Pendapat penulis bahwa keluarga korban tidak pernah diberikan pemahaman terhadap pentingnya dilakukan visum et reperteum oleh pihak kepolisian sebagai alat bukti dalam proses penyidikan. Dalam kasus-kasus ini pihak keluarga korban dibantu dengan Jaringan Advokasi Tambang (Jatam) yang telah membuat laporan ke Komisi Nasional Hak Asasi Manusia (Komnas HAM) yang kemudian langsung melakukan investigasi dengan mengumpulkan data di lokasi kejadian menuju ke Distamben Samarinda untuk meminta konfirmasi dokumendokumen perusahaan yang melakukan aktifitas penambangan di kelurahan Sambutan. Tentang isu penghentian penyidikan karena pencabutan laporan, Komnas HAM berpendapat bahwa tidak ada alasan kepolisian untuk menghentikan penyidikan karena kasus tersebut bukan merupakan delik aduan. Sehingga walaupun sudah ada perdamaian antara keluarga korban dengan pihak perusahaan dengan pemberian uang tali asih, hal tersebut tidak dapat menghapus pertanggungjawaban dari perusahaan terhadap kasus yang ada.

Dari hasil wawancara yang dilakukan penulis berpendapat bahwa alasan keluarga korban menerima pemberian uang tali asih selain menganggap bahwa apa yang menimpa anak-anak mereka adalah merupakan musibah, keluarga korban juga mengakui bahwa adanya kelalaian dari keluarga dalam menjaga anak-anak mereka bermain di lubang tambang yang telah menjadi danau dan digunakan sebagai tempat berenang bagi anak-anak mereka meskipun sudah ada rambu-rambu atau papan larangan yang dipasang oleh perusahaan. Namun semua ini karena kelalaian dari keluarga yang sibuk bekerja sehingga tidak tahu bahwa anak-anak mereka bermain di lubang tambang tersebut. Yang sebenarnya dalam kasus ini bukanlah merupakan sebuah delik aduan seharusnya proses hukum dapat dilanjutkan namun karena semua ini merupakan permintaan dari keluarga korban sendiri yang telah membuat pernyataan perdamaian dengan pihak perusahaan sehingga penyidik mengalami kesulitan dalam menangani kasus tersebut.

\section{Persepsi Hukum Dari Penegak Hukum Atas Penghentian Tindak Pidana}

Kealpaan, seperti juga kesengajaan adalah salah satu bentuk dari kesalahan. Kealpaan adalah bentuk yang lebih rendah derajatnya dari pada kesengajaan. Tetapi dapat pula dikatakan bahwa kealpaan itu adalah kebalikan dari kesengajaan, karena bila mana dalam kesengajaan, sesuatu akibat yang timbul itu dikehendaki, walaupun pelaku dapat memperaktikkan sebelumnya. Disinilah juga letak salah satu kesukaran untuk membedakan antara kesengajaan bersyarat (dolus eventualis) dengan kealpaan berat (culpa lata). 
Dolus Eventualis adalah termasuk kedalam jenis delik dolus yakni delik yang didalamnya terdapat unsurkesengajaan. Kesengajaan disini mempunyai 3 (tiga) tingkatan sebagaimana yang dikemukakan Rusli Effendy yaitu: ${ }^{20}$

1. Sengaja sebagai niat, dalam arti ini akibat delik adalah motif utama untuk adanya suatu perbuatan, yang seandainya tujuan itu tidak ada, maka perbuatan itu tidak akan dilakukan. Misalnya A berniat membunuh B, lalu A menembaknya.

2. Sengaja kesadaran akan kepastian, adalah hal ini ada kesadaran bahwa dengan melakukan perbuatan itu pasti akan terjadi akibat tertentu dari perbuatan itu. Jonkers memberikan contoh sebagai berikut: A hendak menembak mati B yang duduk dibelakan kaca. Untuk mengenai sasarannya itu maka A harus menembak kaca itu sehingga pecah. A bersalah selain daripada membunuh (sengaja sebagai niat) juga telah dengan sengaja merusak barang (kesadaran akan kepastian). Walapun niatnya hanya membunuh B tetapi ia juga menembak kaca itu untuk mencapai maksudnya. A mengetahii bahwa perbuatan (membunuh) bertalian dengan memecahkan kaca.

3. Sengaja insyaf akan kemungkinan, dalam hal ini dengan melakukan perbuatan itu telah diinsyafi kemungkinan yang dapat terjadi dengan dilakukan perbuatan itu.

Mengenai Dolus Eventualis ini, Moeljatno mengemukakan sebagai berikut teori yang dikenal sebagai inkauf nehmen adalah teori mengenai dolus eventualis

20 Rusli Effendy, 1989,Asas-Asas Hukum Pidana, Lembaga Kriminologi Unhas, Ujung Pandang, hal.81 bukan mengenai kesengajaan. Disini ternyata bahwa sesungguhnya akibat dari keadaan yang diketahui kemungkinan akan terjadi, tidak disetujui tetapi meskipun demikian, untuk mencapai apa yang dimaksud resiko akan timbulnya akibat atau disamping maksud itupun diterima. ${ }^{21}$

Andi Zainal Abidin Fadird menggunakan istilah teori apa boleh buat sebagai terjemahan dari inkauf nehmen. Menurut teori ini, untuk adanya kesengajaan (sengaja insyaf akan kemungkinan) harus ada dua syarat: ${ }^{22}$

1. Terdakwa tahu kemungkinan adanya akibat keadaan yang merupakan delik,

2. Sikap tentang kemungkinan itu andai kata timbul ialah apa boleh buat, pikul resikonya.

Mengenai syarat pertama, hal ini dapat dibuktikan dari kecerdasan pikirannya yang dapat disimpulkan antara lain dari pengalamannya, pendidikannya atau lingkungan tempat tinggalnya. Sedangkan mengenai syarat yang kedua, hal ini dapat dibuktikan dari ucapan-ucapan disekitar perbuatan, tidak mengadakan usaha untuk mencegah akibat yang tidak diinginkan tersebut.

Sactohid Kartanegara mengemukakan dasar perbedaan antara dolus dan culpa sebagai berikut: ${ }^{23}$

1. Dolus,

a. Perbuatan itu dilakukan dengan sengaja;

b. Perbuatan itu disebut Doluse delicten;

c. Diancam dengan hukuman yang lebih berat daripada Culpose delicten.

2. Culpa,

a. Perbuatan yang dilakukan karena kalalaian/kealpaan;

${ }^{21}$ Moeljatno, Op.Cit, hal.175

22 Andi Zainal Abidin Fadird, 1995, Hukum Pidana I, Sinar Grafika,Jakarta, hal.217

${ }^{23} \mathrm{Ibid}$ 
b. Perbuatan itu disebut culpose delicten;

c. Ancaman hukumannya adalah lebih ringan daripada doluse delicten.

Antara sengaja insyaf akan kemungkinan (dolus eventualis) dengan culpa lata yang disadari sukar dibedakan, Van

Hattummengemukakan ${ }^{24}$ Seseorang yang bagaimanapun hendak mencapai tujuan yang diperdulukan bahwa orang lain dapat jaga menjadi korban, dan bila akibat itu benar-benar terjadi, maka ia mempunyai gejala insyaf akan kemungkinan (dolus eventualis). Bilamana seseorang itu dalam berusaha mencapai tujuan tersebut di atas, insyaf bahwa kemungkinan orang lain dapat menjadi korban, tetapi diharapkannya mudah-mudahan tidak terjadi korbankorban lain dibatasi sedapat mungkin, maka orang yang demikian itu mempunyai culpa lata yang diinsyafi.

Jonkers berpendapat bahwa dolus eventualis terdapat bilamana pembuat memilih akibat yang diniatkannya ditambah denga akibat yang tidak dikehendakinya, daripada sama sekali tidak berbuat sedangkan culpa yang diinsyafi terdapat bilamana pembuat itu lebih suka tidak berbuat daripada terwujud akibat yang dikehendakinya ditambah dengan akibat yang tidak dikehendakinya. ${ }^{25}$

Maka menjadi jelas bagi kita akan perbedaan diantara keduanya yakni pada dolus eventualis. Meskipun pelaku menginsyafi akan adanya akibat lain yang kemungkinan akan terjadi bilamana ia melakukan perbuatan itu, namun ada rasa ketidakperdulian akan akibat yang mungkin terjadi. Sedangkan bagi culpa latayang diinsyafi, terdapat bilamana pembuat itu lebih suka untuk tidak berbuat daripada terwujudnya akibat yang tidak dikehendaki.

Terkait dengan kealpan atau kelalaian yang mengakibatkan hilangnya nyawa orang lain diatur dalam KUHPidana Buku Kedua tentang Kejahatan yaitu Pasal 359 yang menjelaskan bahwa barang siapa karena kealpaannya menyebabkan matinya orang lain, diancam dengan pidana penjara paling lama lima tahun dan kurungan paling lama satu tahun. Adapun unsur-unsur dari rumusan Pasal 359 KUHP yaitu:

1. Barang Siapa,

Yang dimaksud dengan barang siapa adalah untuk menentukan siapa pelaku delik sebagai objek hukum yang telah melakukan delik tersebut dan memiliki kemampuan mempertanggung jawabkan perbuatannya. Dalam hal ini dimaksud daripada subjek hukum yang memiliki kemampuan bertanggungjawab adalah didasarkan kepada keadaan dan kemampuan jiwa dari pelaku yang didakwakan dalam melakukan delik, yang dalam doktrin hukum pidana ditafsirkan sebagai keadaan sadar.

2. Karena kesalahannya (kelalaian atau kealpaan), dalam unsur ini adalah bahwa matinya korban apakah merupakan akibat dari kelakuan yang tidak dikehendaki oleh terdakwa (orang yang berbuat).

3. Mengakibatkan kematian, dalam unsur ini karena kelalaiannya atau kealpaannya menyebabkan hilangnya nyawa orang lain, maka unsur ini adalah untuk melihat hubungan antara perbuatan yang terjadi dengan akibat yang ditimbulkan sehingga rumusan ini menjadi syarat mutlak dalam delik ini adalah akibat.

\footnotetext{
${ }^{24}$ Ibid, hal.294

${ }^{25}$ Ibid
} 
Dalam kenyataannya penyelesaian perkara yang menyebabkan hilangnya nyawa seseorang sering kali dilakukan dengan cara di luar pengadilan yaitu dengan melakukan kesepakatan dengan tujuan agar tercapai perdamaian. Hal ini tentunya bertentangan dengan hukum pidana sebagai hukum publik. Adapun hukum pidana dapat dicirikan sebagai berikut: ${ }^{26}$

1. Mengatur hubungan antara kepentingan negara atau masyarakat dengan orang perorangan;

2. Kedudukan penguasa negara adalah lebih tinggi daripada orang perorangan. Dengan perkataan lain, orang perorangan disubordinasikan kepada penguasa;

3. Penuntutan seseorang yang telah melakukan suatu tindakan terlarang tidak tergantung kepada perseorangan yang dirugikan, melainkan pada umumnya, negara/penguasa wajib menuntut seseorang tersebut;

4. Hal subjektif penguasa ditimbulkan oleh peraturan-peraturan hukum pidana objektif atau hukum pidana positif.

Dalam perkembangan wacana teoritik maupun perkembangan pembaruan hukum pidana diberbagai negara ada kecenderungan kuat untuk menggunakan mediasi pidana/penal sebagai salah satu alternatif penyelesaian masalah di bidang hukum pidana. Menurut Barda Nawawi Arief, mediasi pidana yang dikembangkan itu bertolak dari ide dan prinsip kerja sebagai berikut: ${ }^{27}$

1. Penanganan Konflik, tugas mediator adalah membuat para pihak melupakan kerangka hukum dan mendorong mereka terlibat dalam proses

26 Erdianto Effendi, 2011, Hukum Pidana Indonesia Suatu Pengantar, Refika Aditama, Pekanbaru, hal.46

${ }^{27}$ Barda Nawawi Arief, Op.Cit, hal.6 komunikasi. Hal ini didasarkan pada ide, bahwa kejahatan telah menimbulkan konflik interpersonal. Konflik itulah yang dituju oleh proses mediasi.

2. Berorientasi pada proses, mediasi penal lebih berorientasi pada kualitas proses daripada hasil, yaitu menyadarkan pelaku tindak pidana akan kesalahannya, kebutuhankebutuhan konflik perpecahan, ketenangan korban dari rasa takut dan sebagainya.

3. Proses informal, mediasi penal merupakan suatu proses yang informal, tidak bersifat birokratis, menghindari prosedur hukum yang ketat.

Sebagaimana diatur dalam Peraturan Kapolri Nomor 14 tahun2012 tentang Manajemen Penyidikan TindakPidana (Perkap 14/2012) dan Peraturan Kepala Bareskrim Polri Peraturan Kepala Badan ReserseKriminal Kepolisian Negara Republik Indonesia Nomor 2 Tahun 2014 tentang Standar OperasionalProsedur Pengorganisasian Penyidikan Tindak Pidana (Perkaba 2/2014) yang menjadi dasar kewenangan kepolisian dalam menerbitkan SP3 salah satunya adalah tidak terdapat cukup bukti. Jika polisi penyidik tidak memperoleh cukup bukti untuk menuntut tersangka atau bukti yang diperoleh oleh polisi penyidik tidak memadai untuk membuktikan kesalahan tersangka di hadapan persidangan, penyidik berwenang memutuskan penghentian penyidikan. Ukuran kapan dan bilamana dalam penyidikan harus dihentikan ditentukan dari tersedianya minimal dua alat bukti yang sah.

Pendapat penulis bahwa penegak hukum dalam hal telah terjadinya kesepakatan perdamaian antara pihak perusahaan dan keluarga korban maka sesuai dengan isi dari kesepakatan bersama 
bahwa tidak akan menuntut dikemudian hari. Hal ini menjadi dasar alasan pihak kepolisian untuk tidak meneruskan proses perkara tersebut, selain daripada itu alasan lainnya adalah bukti yang kurang seperti tidak adanya visum et repertum karena pihak keluarga keberatan jika anaknya dilakukan visum, membuat perkara tersebut sulit untuk dapat ditingkatkan. Sehingga jalan satu-satunya yang dapat ditempuh adalah dengan cara penyelesaian perkara diluar pengadilan yakni dengan dilakukannya mediasi pidana atau dikenal dengan istilah mediasi penal. Namun apabila dikemudian hari terdapat desakan/permintaan pihak berkepentingan dan ditemukan alat bukti yang cukup maka perkara tersebut dapat dibuka kembali.

\section{PENGATURAN SURAT PERINTAH PENGHENTIAN PENYIDIKAN TERHADAP KASUS KORBAN MENINGGAL DUNIA PADA SASARAN PENYIDIKAN YANG MELIBATKAN KORPORASI}

\section{A. Prosedur Penerbitan Surat Perintah Penghentian Penyidikan}

Seperti yang telah dijelaskan pada bab sebelumnya bahwa dasar bagi pihak kepolisian untuk menerbitkan SP3 bukan saja ketentuan pada Pasal 109 UndangUndang Nomor 8 Tahun 1981 tentang Kitab Undang-Undang Hukum Acara Pidana. Sekalipun pada Pasal 109 ayat (2) KUHAP diatur alasan formal penerbitan SP3. Bagi penyelidikan dari kepolisian, ketentuan yang lebih penting dan jaraknya tidak terlalu jauh dan sebab itu menjadi acuan konkrit yang mengatur perilaku mereka adalah Peraturan Kapolri Nomor 14 tahun 2012 tentang Manajemen Penyidikan Tindak Pidana (Perkap 14/2012) dan Peraturan Kepala Bareskrim Polri Peraturan Kepala Badan Reserse Kriminal Kepolisian
Negara Republik Indonesia Nomor 2 Tahun 2014 tentang Standar Operasional Prosedur Pengorganisasian Penyidikan Tindak Pidana (Perkaba 2/2014). Ketentuan Pasal 76 ayat (1) Perkap 14/2012 mengatur bahwa:

Penghentian penyidikan sebagaimana dimaksud dalam Pasal 15 huruf (i), dilakukan apabila:

1. Tidak terdapat cukup bukti;

2. Peristiwa tersebut bukan merupakan tindak pidana; dan

3. Demi hukum, karena tersangka meninggal dunia, perkata telah kadaluarsa, pengaduan dicabut (khusus delik aduan); dan tindak pidana tersebut telah memperoleh putusan hakim yang mempunyai kekuatan hukum tetap (nebis in idem).

Putusan untuk menghentikan atau meneruskan penyidikan dipengaruhi juga oleh mekanisme dan prosedur panjang yang mengikat penyidik. Dalam hal ini yang berlaku adalah aturan-aturan internal yang dibuat oleh kepolisian untuk mengelola dan mengendalikan kewenangan yang diberikan pada penyelidik-penyidik. Prosedur dan mekanisme (aturan internal) ini dapat kita temukan dalam wujud Peraturan Kepala Badan Reserse Kriminal Kepolisian Negara Republik Indonesia Nomor 2 Tahun 2014 tentang Standar Operasional Prosedur Pengorganisasian Penyidikan Tindak Pidana (Perkabareskrim No. 2/2014) beserta Lampiran A (Standar Operasional Prosedur Penunjukan Penyidik/Penyidik Pembantu),dan Lampiran B (Standar Operasional Prosedur Pelaksanaan Penyelidikan dan Penyidikan Tindak Pidana) serta Peraturan Kepala Badan Reserse Kriminal Kepolisian Negara Republik Indonesia Nomor 3 Tahun 2014 (Perkabareskrim No. 3/2014) tentang Standar Operasional Prosedur Pelaksanaan Penyidikan Tindak Pidana. 
Kedua PerKaBareskrim di atas merupakan policy regulation atau beleidsregels yang pada akhirnya menjadi pedoman paling dekat, konkrit, terkini dan paling nyata bagi anggota Kepolisian penyidik dalam memutus menghentikan atau meneruskan perkara. Ini tentu berbanding terbalik dengan AUPB dan Kode Etik Kepolisian yang masih bersifat abstrak dan umum dan belum tentu secara konkret dan langsung berpengaruh terhadap pelaksanaan kegiatan penyelidikan atau penyidikan. Ini tercermin pula dari aturanaturan yang termuat di dalamnya yang bersifat teknis-prosedural dan sebab itu dipergunakan sebagai pedoman (atau petunjuk pelaksanaan atau petunjuk teknis) untuk melakukan kegiatan penyelidikanpenyidikan langkah demi langkah.

Salah satu pranata hukum terpenting yang membatasi kewenangan diskresioner penyidik polisi untuk memutuskan atau tidak memutuskan menerbitkan SP3 adalah Gelar Perkara. Penyidik polisi tidak dapat menerbitkan SP3 tanpa terlebih dahulu melakukan Gelar Perkara (khusus) dan secara nyata hal ini ditegaskan pula dalam ketentuan Pasal 76 ayat (2) PerKap No. 14/2012: "Sebelum dilakukan penghentian penyidikan, wajib dilakukan gelar perkara". Pertanyaan penting di sini ialah seberapa sering gelar perkara ini harus dilakukan dan atas beban biaya siapa. Hal ini patut dipertanyakan mengingat keterbatasan sumber daya Kepolisian dan perlunya penanganan perkara secara cepat dan efisien.

Selanjutnya seberapa jauh gelar perkara khusus ini terbuka dan perlu di informasikan kepada pihak pelapor atau (keluarga) korban tindak pidana. Seberapa jauhkah pihak pelapor atau keluarga korban atau mereka yang berkepentingan dengan satu dan lain cara perlu dilibatkan atau mendapat informasi perihal hasil akhir gelar perkara khusus ini.
Persoalan di atas layak ditanyakan karena sebenarnya gelar perkara sebagai suatu prosedur penting dalam hukum acara pidana tidak ditemukan pengaturannya didalam KUHAP. Gelar perkara diatur didalam ketentuan Pasal 69 sampai dengan Pasal 72 PerKap tersebut. Ketentuan Pasal 69 PerKap No. 14/ 2012 menyebutkan adanya dua jenis gelar perkara: gelar perkara biasa dan gelar perkara khusus. Perbedaan diantara keduanya adalah gelar perkara biasa dilakukan, antara lain untuk memutuskan apakah perlu atau tidak diterbitkan SP3.

Selanjutnya berdasarkan ketentuan Pasal 70 ayat (1) PerKap No. 12/2014 dapat disimpulkan bahwa gelar perkara setidaknya dilakukan tiga kali untuk setiap kasus yang sedang ditangani penyidik Kepolisian. Sedangkan gelar perkara khusus, menurut ketentuan Pasal 71 ayat (1) PerKap No. 12/2014, akan dilaksanakan jika ada putusan Pra-Peradilan yang menyatakan bahwa SP3 ditolak dan artinya ada perintah pengadilan untuk melanjutkan penyidikan.

Melalui gelar perkara (biasa) ditentukan pula apakah penanganan perkara dapat ditingkatkan statusnya dari penyelidikan ke penyidikan, serta apakah penyidikan diteruskan atau kemudian dinyatakan selesai.Tidak tersebut secara eksplisit dalam prosedur di atas namun acap muncul dalam praktik adalah prosedur penghentian penyelidikan, yang diambil bilamana perkara yang bersangkutan (dinilai) bukan tindak pidana,atau pelapor mencabut aduannya (dalam hal perkara yang bersangkutan adalah delik aduan). Untuk menghentikan penyelidikan perkara, Kepolisian akan menerbitkan Surat Pemberitahuan Perkembangan Hasil Penyidikan (SP2HP) model A2. Kewenangan penerbitan SP2HP-A2 sebenarnya tidak memiliki dasar hukum (tertulis; peraturan perundang-undangan). 
Artinya, secara yuridis formal, tidak tersedia pula upaya hukum untuk melawan atau menyanggah validitas atau keabsahan SP2HP-A2 yang menghentikan penyelidikan. Ini berbeda dengan penerbitan SP3 yang terhadapnya,menurut KUHAP, dapat diajukan Pra-Peradilan.

Dapat dibayangkan dalam konteks ini bahwa penyelidikan merupakan tahap seleksi perkara yang dilakukan internal oleh penyelidik-penyidik. Hanya kasus-kasus yang dianggap layak untuk diteruskan akan disidik, terhadap yang tidak lolos seleksi tahap pertama ini akan diterbitkan SP2HPA2. Kuat dugaan bahwa alasan adanya SP2HP-A2 terkait dengan adanya pembedaan (dalam KUHAP) antara proses penyelidikan dan proses penyidikan. Beleidsregel (aturan kebijakan yang memuat prosedur operasional baku) ini tampaknya dibuat untuk mengisi kekosongan hukum dalam KUHAP, khusus untuk mengatur transisi dari tahap penyelidikan ke penyidikan. Yang harus dilakukan dalam gelar perkara adalah penyidik memaparkan hasil penyidikan atau perkembangan penanganan perkara dihadapan atasan atau rekan-rekan kerjanya dengan tujuan mendapat masukan pertimbangan dan arahan kebijakan. Dengan kata lain, gelar perkara adalah forum tanya jawab dan diskusi. Didalam gelar perkara kadang pula diundang ahli/pakar di bidang terkait dengan perkara yang sedang disidik. Ahli di sini adalah pakar yang memiliki kompetensi khusus disuatu bidang tertentu (hukum maupun non-hukum) dan dianggap mampu memberikan masukan berdasarkan keahliannya. Karena gelar perkara pada prinsipnya adalah untuk kepentingan penyidikan, maka acara ini tidak terbuka untuk umum. Pihak pelapor atau pengacara seandainya pun diminta hadir hanya diperkenankan menjadi pengamat belaka.
Namun demikian, peraturan internal Kepolisian tidak memuat sanksi administratif apabila "kewajiban" gelar perkara tidak dijalankannya. Menurut ketentuan Pasal 83 PerKap No. 14/2012, gelar perkara sebagai satu bagian dari prosedur operasional baku, dikembangkan hanya sebagai salah satu metode (internal) kepolisian dalam rangka pengawasan dan pengendalian kegiatan penyidikan.

Di luar itu, Kepolisian untuk mengawasi dan mengendalikan kegiatan penyidikan (termasuk penggunaan upaya paksa dan pengambilan keputusan menghentikan penyelidikan-penyidikan atau justru meneruskannya) menggunakan metoda lainnya seperti pembuatan dan penelitian laporan, pengawasan melekat, petunjuk dan arahan, serta supervisi langsung/tidak langsung. Maka dapat pula dimengerti mengapa di dalam praktiknya, keputusan untuk melakukan atau tidak melakukan gelar perkara (biasa atau khusus) digantungkan pada pertimbangan berat/ringan kasus yang ditangani. Artinya, keputusan untuk melakukan gelar perkara digantungkan pada kebutuhan polisi penyidik sendiri.

Keputusan menghentikan atau sebaliknya meneruskan penyidikan adalah keputusan resmi yang diperoleh secara kolektif (sebagai hasil akhir dari proses gelar perkara). Artinya, keputusan penghentian penyidikan adalah keputusan resmi dari penyidik (atau lembaga Kepolisian) dengan irah-irah "Pro Justitia" yang bersifat individual-konkrit (untuk perkara A dengan korban atau pihak pelapor dan terlapor tertentu dan tersangka tertentu pula). Namun apakah keputusan ini harus dituangkan dalam bentuk tertulis sebagai surat keputusan (beschikking) yang kemudian terhadapnya dapat diajukan gugatan ke hadapan Pengadilan Tata Usaha Negara. 
Pada prakteknya, sebagaimana juga di indikasikan di atas, penyidikan dapat dihentikan secara formal maupun informal. Penghentian penyidikan secara formal dilakukan dengan terbitnya SP3 yang dibuat sesuai peraturan perundang-undangan dan beleidsregel yang ada. Sedangkan penghentian penyidikan secara informal dilakukan dengan tidak ada penerbitan surat secara khusus, sehingga kasus akan didiamkan (atau sering disebut juga ice box). Surat (keputusan tertulis) juga dianggap tidak perlu bilamana penghentian penyidikan terjadi karena para pihak telah melakukan perdamaian dan (dilanjutkan dengan pencabutan laporan untuk tindak pidana aduan). Jadi SP3 yang merupakan kewenangan penyidik dimaksudkan sebagai upaya lain sebelum perkara yang sedang disidik berlanjut pada tahapan penegakan hukum selanjutnya.

Penerbitan SP3 dapat menimbulkan kecurigaan publik apabila tidak disertai dengan alasan kuat mengapa SP3 tersebut diterbitkan. Sebaliknya keputusan SP3 baru akan dituangkan dalam bentuk surat tertulis (resmi) hanya dalam hal kasus yang ditangani penyidik adalah kasus yang disorot masyarakat banyak (atau mendapat liputan luas dari media masa), misalnya kasus lingkungan hidup. Kemungkinan lain ialah jika pihak yang berkepentingan (pelapor, lembaga swadaya masyarakat atau LBH) secara khusus mendesak dan meminta diterbitkannya SP3 tersebut. Hal ini juga dilakukan atas permintaan khusus (atensi) dari "orang" (pejabat/petinggi yang berkedudukan sebagai pelapor atau tersangka). SP3 dalam bentuk tertulis tersebut akan dikirimkan kepada pelapor, jaksa penuntut umum, tersangka dan/atau kuasanya. Urusan menghentikan penyelidikan (dengan SP2HP-A2) atau penyidikan (dengan atau tanpa melalui gelar perkara dan penerbitan SP3: dalam bentuk Surat Keputusan ataupun tidak) lebih dipandang sebagai urusan internal Kepolisian. Kriteria yang digunakan oleh penyidik dan yang diputuskan dalam gelar perkara kemungkinan besar sangat teknis,tidak dimengerti oleh masyarakat awam atau sebaliknya sangat tidak jelas (kabur) setidaknya bagi awam. Kesulitan lain di sini muncul dari tertib administrasi. Dalam satu kasus pelapor menerima SP2HP-A2 padahal SP3 telah diterbitkan. Namun seberapa sering dan jauh tidak tertib ini berpengaruh terhadap "kepastian dan kejelasan" prosedur penghentian penyelidikan-penyidikan tidak dapat diketahui. Namun diakui pula oleh Kepolisian bahwa masalah prosedural ini perlu ditangani dan dibereskan.

Dari sudut pandang masyarakat atau pengamat luar kerap dipertanyakan mengapa satu kasus diputus SP3 sedangkan lainnya justru dilanjutkan penyidikannya. Pertanggungjawaban polisi penyidik terkesan lebih mengutamakan atasan langsung dan lembaga Kepolisian, bukan pada pihak yang berkepentingan ( pelapor atau terlapor atau masyarakat umum) dengan penegakan hukum pidana. Bilamana ditengarai ada penyimpangan atau penyalahgunaan wewenang yang dilakukan penyidik, maka pihak yang bersalah (penyidik) harus dikenakan tindakankoreksi dan terhadapnya dikenakan sanksi administrasi atas tindakan pelanggaran yang dilakukannya secara proporsional.

Dapat dibayangkan bahwa tindakan tersebut dimaksudkan untuk mencegah adanya intervensi (dari korban atau keluarga korban atau pun masyarakat umum) terhadap pengambilan keputusan polisi penyidik berkaitan dengan perkara (kasus pidana) yang sedang ditanganinya. Betul bahwa penyalahgunaan kewenangan tersebut,termasuk dalam hal pemberdayaan upaya paksa, dapat memunculkan reaksi internal dari kepolisian. Namun jangkauan tindakan koreksional, bilapun ada ditujukan 
lebih pada penjagaan martabat dan profesionalitaspolisi penyidik. Dengan kata lain, sekalipunmungkin dapat memuaskan pihak yang dirugikan, tindakan koreksional (dijatuhkan internal) tidak akan langsung berpengaruh terhadap upaya untuk membuka kembali perkara yang secara tidak sah telah dihentikan penyidikannya.

Pentingnya pertanggungjawaban polisi penyidik atas keputusan untuk menggunakan kewenangan diskresioner (termasuk dalam penetapan SP3 dengan atau tanpa gelar perkara, bahkan penghentian penyelidikan)harus dikaitkan dengan peluang bagi pihakyang dirugikan dengan SP3 (resmi/ tidakresmi; tertulis/ tidak) untuk menyanggah keputusan itu (melalui upaya hukum yang tersedia dalam sistem peradilan pidana atau di luar itu) dan dengan demikian memaksa penyidik untuk membuka kembali kasus dan meneruskan penyidikan dan menerima risiko lain dari disanggahnya validitas dari keputusan yang telah dibuat (tuntutan ganti rugi dari pihak yang merasa dirugikan oleh keputusan penghentian penyidikan).

\section{B. Pertanggungjawaban Korporasi Dalam Kasus Lubang Tambang}

Dasar hukum pertanggungjawaban korporasi dalam kasus lubang tambang tidak terlepas dari Peraturan Mahkamah Agung Nomor 13 Tahun 2016 tentang Tata Cara Penanganan Perkara Tindak Pidana Oleh Korporasi. Dijelaskan dalam aturan tersebut bahwa tindak pidana oleh korporasi merupakan tindak pidana yang dilakukan oleh orang berdasarkan hubungan kerja, atau berdasarkan hubungan lain, baik sendiri-sendiri maupun bersama-sama yang bertindak untuk dan atas nama korporasi di dalam maupun di luar lingkungan korporasi.

Pertangungjawaban pidana korporasi yang dijelaskan didalam peraturan Mahkamah Agung tersebut dapat dikategorikan sebagai tanggung jawab mutlak atau biasa disebut dengan strict liability. Konsep tanggung jawab mutlak ini berbeda dengan sistem tanggung jawab pidana umum yang mengharuskan adanya kesengajaan atau kealpaan. Dalam sistem tanggung jawab mutlak hanya dibutuhkan pengetahuan dan perbuatan dari terdakwa. Artinya dalam melakukan perbuatan tersebut, apabila si terdakwa mengetahui dan menyadari tentang potensi kerugian bagi pihak lain, maka keadaan ini cukup untuk menuntut pertanggungjawaban pidananya.

Konsep tanggung jawab mutlak atau strict liability pertama kali diperkenalkan dalam hukum Indonesia melalui UndangUndang Nomor 23 Tahun 1997 tentang Pengelolaan Lingkungan Hidup yang selanjutnya dirubah dengan UndangUndang Nomor 32 Tahun 2009 tentang Perlindungan dan Pengelolaan Lingkungan Hidup. Dalam Pasal 88 Undang-Undang Perlindungan dan Pengelolaan Lingkungan Hidup dijelaskan bahwa setiap orang yang tindakannya, usahanya, dan/atau kegiatannya menggunakan B3, menghasilkan dan/atau mengelola limbah B3, dan/atau yang menimbulkan ancaman serius terhadap lingkungan hidup bertanggungjawab mutlak atas kerugian yang terjadi tanpa perlu pembuktian unsur kesalahan. Yang kemudian didalam penjelasan pasal tersebut disebutkan bahwa yang dimaksud dengan bertanggung jawab mutlak atau strict liability adalah unsur kesalahan tidak perlu dibuktikan oleh pihak penggugat sebagai dasar pembayaran ganti rugi. Ketentuan ayat ini merupakan lex specialis dalam gugatan tentang perbuatan melanggar hukum pada umumnya. Besarnya nilai ganti rugi yang dapat dibebankan terhadap pencemaran atau perusak lingkungan hidup menurut pasal ini dapat ditetapkan sampai batas tertentu. 
Berdasarkan konsepvicarious liability ini, pelaku usaha dapat dituntut bertanggung jawab atas perbuatannya, termasuk perbuatan orang lain tetapi masih di dalam lingkungan aktivitas usahanya atau akibat yang bersumber dari aktivitasnya yang dapat merugikan orang lain. Pimpinan korporasi atau siapa saja yang memberi tugas atau perintah bertanggung jawab atas perbuatan yang dilakukan oleh bawahan atau karyawannya. Tanggung jawab ini diperluas hingga mencakup perbuatan-perbuatan yang dilakukan oleh orang-orang berdasarkan hubungan kerja maupun hubungan lain. Dengan demikian, siapa saja yang bekerja dan dalam hubungan apa saja pekerjaan itu dilakukan, selama hal tersebut dilakukan dalam hubungannya dengan korporasi, menjadi tanggung jawab korporasi.

Dalam kasus meninggalnya seseorang di lubang tambang, penulis melihat bahwa ini merupakan pertanggungjawaban pidana yang ditujukan kepada korporasi. Artinya bahwa disini tindakan yang dilakukan oleh korporasi adalah merupakan tindakan dari seluruh individu-individu di dalam korporasi bukan perseorangan, sehingga dalam kasus ini tidak dapat kita melihat hanya dari segi pertanggungjawaban pidana dari seorang direktur sebuah perusahaan. Tanggung jawab atas tindak pidana korporasi harus mampu mengalokasikan tanggung jawab kepada setiap pihak yang harus bertanggung jawab, sehingga menghindari kemungkinan dikorbankannya pihak tertentu dalam korporasi sebagai kambing hitam misalnya dalam hal ini paling sering korporasi diwakili oleh direktur sehingga direkturlah dianggap yang paling besar kesalahannya. Tetapi harus dilihat bahwa direktur hanyalah mewakili korporasi atau perusahaan membawahi individu-individu lainnya yang ada didalam korporasi tersebut, direktur tidak bertindak atas nama dirinya sendiri dalam membuat suatu keputusan.

Di dalam teori pertanggungjawaban korporasi terdapat teori pertanggung jawaban pengganti atau dikenal dengan istilah vicarious liability. Pertanggungjawaban pengganti (disebut dengan vicarious liability atau respondeat superior) merupakan salah satu bentuk pertanggungjawaban korporasi yang paling banyak diterapkan di berbagai negara. Dalam pertanggungjawaban ini, korporasi bertanggungjawab atas tindak pidana yang dilakukan oleh seorang pekerjanya, tanpa melihat status atau kedudukan orang tersebut di dalam korporasi. Dalam hal ini, Feinberg sebagaimana dikutip oleh Harding, menyatakan bahwa vicarious liability adalah pertanggungjawaban kolektif, di mana organisasi bertanggungjawab atas perbuatan dari anggotanya. $^{28}$

Penerapan vicarious liability dalam dilihat pada Pasal 4 Peraturan Mahkamah Agung Nomor 13 Tahun 2016 tentang Tata Cara Penanganan Perkara Tindak Pidana Oleh Korporasi menjelaskan bahwa:

1. Korporasi dapat dimintakan pertanggungjawaban pidana sesuai dengan ketentuan pidana korporasi dalam undang-undang yang mengatur tentang korporasi;

2. Dalam menjatuhkan pidana terhadap korporasi, hakim dapat menilai kesalahan korporasi sebagaimana ayat (1) antara lain:

a. Korporasi dapat memperoleh keuntungan atau manfaat dari tindak pidana tersebut atau tindak pidana tersebut dilakukan untuk kepentingan Korporasi;

b. Korporasi membiarkan terjadinya tindak pidana; atau

28 Christopher Harding, 2007, Criminal Enterprise: Individuals, Organisations and Criminal Responsibility, Willan Publishing, Portland, hal.87 
c. Korporasi tidak melakukan langkah-langkah yang diperlukan untuk melakukan pencegahan, mencegah dampak yang lebih besar dan memastikan kepatuhan terhadap ketentuan hukum yang berlaku guna menghindari terjadinya tindak pidana.

Walaupun pertanggungjawaban pidana terhadap suatu korporasi telah diatur di dalam Peraturan Mahkamah Agung Nomor 13 Tahun 2016 tentang Tata Cara Penanganan Perkara Tindak Pidana, namun dalam pelaksanaan sanksi bagi korporasi yang melakukan suatu tindak pidana hanya dapat dikenakan sanksi pokok yaitu berupa sanksi denda. Bagaimana dengan pertanggungjawaban pidana korporasi terhadap kasus meninggalnya seseorang di lubang tambang yang apabila berdasarkan ketentuan peraturan pidana karena kelalaian yang menyebabkan meninggalnya seseorang dapat diancam dengan hukuman penjara selama 5 (lima) tahun. Tentunya nilai kepuasan dari keluarga korban apabila diukur dari sejumlah uang dalam menerima ganti kerugian berbeda satu sama lain. Apalagi jika sanksi pokok berupa sanksi denda berdasarkan peraturan Mahkamah Agung tersebut tentunya denda yang harus dibayar oleh korporasi merupakan hak dari negara bukan ditujukan kepada keluarga korban.

\section{PENUTUP KESIMPULAN DAN SARAN}

Berdasarkan dari analisis yang termuat di dalam pembahasan, maka dapat disimpulkan bahwa:

1. Surat kesepakatan yang dibuat oleh pelaku dan pihak korban dalam peristiwa hilangnya jiwa seseorang sejatinya tidak serta merta menghapus pertanggungjawaban pidana terhadap yang melakukannya.
2. Terjadi pergeseran persepsi sosial, dalam menilai alasan peniadaan pertanggungjawaban hukum pidana atas hilangnya nyawa dengan kualifikasi culva lata dan dolus eventualis. Persepsi Sosial Penghentian tersebut berlawanan dengan hukum pidana yang diterapkan di Indonesia dalam hal ini perlu ada proses lanjut, sehingga ada pertanggungjawaban hukum.

3. Pengaturan surat perintah penghentian penyidikan terhadap kasus korban meninggal dunia yang melibatkan korporasi tidak memiliki perbedaan dengan subyek pelaku lainya sepanjang ada alasan yang cukup dalam hal ini tidak memiliki unsurunsur pidana termasuk bukti yang cukup dan bernilai hukum.

Adapun saran-saran yang dapat disampaikan adalah:

1. Agar terwujud penegakan hukum yang memiliki kemanfaatan, kepastian hukum dan rasa keadilan bagi pelaku dan korban hendaknya dilakukan pembaharuan hukum pidana terhadap kesepakatan yang dilakukan oleh pelaku dan korban yang merupakan dimensi hukum privat ke dalam hukum publik.

2. Perlu dibentuk sebuah lembaga pengawasan terhadap penyelesaian perkara di luar pengadilan yang bertugas mengawasi seluruh proses mediasi yang dilakukan oleh pihak pelaku dan korban, agar dapat memberikan keadilan sepenuhnya kepada korban dan juga kepada pelaku sehingga tercapai penegakan hukum yang berlandaskan pada asas kemanfaatan, kepastian hukum dan keadilan.

3. Agar penyidik kepolisian dapat menjalankan kewenangan diskresioner 
yang diberikan dengan penuh tanggungjawab, maka perlu penyidik kepolisian untuk diberikan pelatihan dan pendidikan agar dapat menjalankan kebebasan kebijaksanaan dan kebebasan penilaian terutama

\section{DAFTAR PUSTAKA}

\section{Buku/Literatur :}

Alef Musyahadah R, 2005, "Kedudukan Perdamaian Antara Korban Dengan Pelaku Tindak Pidana Dalam Sistem Pemidanaan" Tesis, Program Pasca Sarjana Universitas Diponegoro, Semarang;

Andi Hamzah, 2001, Bunga Rampai Hukum Pidana dan Acara Pidana, GhaliaIndonesia, Jakarta, 2001;

Andi Zainal Abidin Fadird, 1995, Hukum Pidana I, Sinar Grafika, Jakarta;

Barda Nawawi Arief, 2008, Mediasi Penal Penyelesaian Perkara Diluar Pengadilan, Pustaka Magister, Semarang;

Barda Nawawi Arief, 2004, Masalah Pemidanaan sehubungan dengan perkembangan kriminalitas dan perkembangan delik-delik khusus, Utomo, Bandung;

Barda Nawawi Arief, 2003, Kapita Selekta Hukum Pidana, Citra Aditya Bakti, Bandung;

Barda Nawawi Arief, 1990, Perbandingan Hukum Pidana, Rajawali Pers, Jakarta; ketika berhadapan dengan normanorma yang tidak selamanya jelas. Sehingga penyidik kepolisian tidak menyalahgunakan diskresioner secara sewenang-wenangnya.
Basyir Daud, 2017, Samarinda Menggugat; ketika kegelisahan menjadi kemarahan, Jaringan Advokasi Tambang (JATAM), Jakarta;

Chairul Huda, 2006, Dari "Tiada pidana tanap Kesalahan" menuju kepada "Tiada Pertanggungjawaban Pidana Tanpa Kesalahan”; Tinjauan Kritis Terhadap Teori PemisahanTindak Pidana dan Pertanggungjawaban Pidana, Pranada Media, Jakarta;

Christopher Harding, 2007, Criminal Enterprise: Individuals, Organisations and Criminal Responsibility, Willan Publishing, Portland;

Djoko Prakoso, 1988, Surat Dakwaan,Tuntutan Pidana dan Eksaminasi Perkara di Dalam Proses Pidana, Liberty, Yogyakarta;

Dwidja Priyatno, 2004, Kebijakan Legislasi Tentang Sistem Pertanggungjawaban Pidana Korporasi di Indonesia, Utomo, Bandung;

E.Y.Kanter, S.R Sianturi, 2002,Asas-asas Hukum Pidana di Indonesia dan Penerapannya, Storia Grafika, Jakarta; 
Erdianto Effendi, 2011, Hukum Pidana Indonesia Suatu Pengantar, Refika Aditama, Pekanbaru;

H.Salim, Erlies Septiana Nurbani, 2016, Penerapan Teori Hukum Pada Penelitian Disertasi dan Tesis Buku Ketiga, RajaGrafindo Persada, Jakarta;

H.Setiyono, 2002, Kejahatan Korporasi, Averroes Press, Malang;

Mardhono Reksodiputro, 2012, Kejahatan Korporasi Suatu Fenomena Lama Dalam Bentuk Baru, Jurnal Hukum Internasional, Vo.1 No.4;

Moeljatno, 2000, Asas-Asas Hukum Pidana, Rineka Cipta, Jakarta;

Lamintang, 1988, Hukum Penitensier Indonesia, Armico, Bandung;

Lamintang, 1996, Dasar-Dasar Hukum Pidana Indonesia, Citra Adityta Bakti, Bandung;

Lilik Mulyadi, 2016, Implementasi Mediasi Penal Sebagai Perwujudan NilaiNilai Pancasila Guna Mendukung Supremasi Hukum Dalam Rangka Pembangunan Hukum Nasional, Genta Publishing, Yogyakarta;

Marc Levin dalam Eva Achjani Zulfa, 2011, Pergeseran Paradigma Pemidanaan, Lubuk Agung, Bandung;

Moeljatno, 1993, Asas-Asas Hukum Pidana, Rineka Cipta, Jakarta;

Muladi, Dwidja Priyatno, 2010, Pertanggungjawaban Pidana Korporasi, Kencana, Jakarta;
Muladi, 1995, Kapita Selekta Sistem Peradilan Pidana, Badan Penerbit Universitas Diponegoro, Semarang;

Mushadi, 2007, Mediasi dan Resolusi Konflik di Indonesia, Walisongo Mediator Center, Semarang;

Mudzakkir, 2013, Mediasi Penal Penerapan Nilai-Nilai Restoratif Justice dalam penyelesaian tindak pidana adat bali, tesis, fakultas hukum Universitas Indonesia, Jakarta;

P.A.F. Lamintang, 1996,Dasar-Dasar Hukum Pidana Indonesia, Citra Adityta Bakti, Bandung;

Roeslan Saleh, 1983, Perbuatan Pidana dan Pertanggungjawaban Pidana; Dua Pengertian. Dasar dalam Hukum Pidana, Cetakan ketiga, Aksara Baru, Jakarta;

Roeslan Saleh, 1982, Pikiran-Pikiran Tentang Pertanggungjawaban Pidana, Ghalia Indonesia, Jakarta;

Rusli Effendy, 1989,Asas-Asas Hukum Pidana, Lembaga Kriminologi Unhas, Ujung Pandang;

Salim HS, 2012, Hukum Pertambangan Indonesia. Rajawali Pers, Jakarta;

Sally Simpson, 2002, Corporate Crime, Law and Social Control, Cambridge University Press, New York;

Sutan Remy Sjahdeni, 2007, Pertanggungjawaban Pidana Korporasi, Grafiti Pers, Jakarta; 
Tri Andrisman, 2009,Asas-Asas dan Aturan UmumHukum Pidana Indonesia, Universitas Lampung, Bandar Lampung;

Widiyono, 2004, Wewenang Dan Tanggung Jawab, Ghalia Indonesia, Bogor;

Wirjono Prodjodikoro, 1981, Hukum Acara Pidana di Indonesia, Sumur, Bandung;

Zainal Abidin Farid, 2007, Hukum Pidana I, Sinar Grafika, Jakarta.

\section{Peraturan Perundang-undangan :}

Undang-Undang Dasar Negara Republik Indonesia Tahun 1945;

Kitab Undang-Undang Hukum Pidana;

Kitab Undang-Undang Hukum Acara Pidana.

\section{Jurnal}

Mardhono Reksodiputro, 2012, Kejahatan Korporasi Suatu Fenomena Lama Dalam Bentuk Baru, Jurnal Hukum Internasional, Vo.1 No.4
Richard Card, 1999, Reformasi Pertanggungjawaban Pidana, Jurnal Ilmu Hukum No.11 Vo.6

\section{Website}

https://www.jatam.org/2017/07/05/lagilubang-maut-batu-bara-makankorban/ diakses pada tanggal $30 \mathrm{Juli}$ 2017, Pukul 20.06 Wita 